Nie Hongyin

\title{
A Unique Tangut Primary Reader Brief Collection by Taizong kept in the IOM RAS
}

DOI 10.17816/wmo34968

Abstract: The previously undesiphered manuscript inv. № 5875 preserved in the Institute of Oriental Manuscripts, Russian Academy of Sciences, proves to be the Tangut version of a primary reader. Its Chinese original is an inconsistently miscellaneous compilation of ancient literary allusions and contemporary folk maxims. The text is composed by different literary style of antithetical couplet and ordinary prose without a consistent subject. Although its Chinese original has not been found yet and the whole text has not been thoroughly deciphered so far, narrations and translations may be provided as many as possible in the present paper in order to lay a foundation for further studies.

Key words: Tangut; translation; primary reader; antithetical couplet; folk maxim

\section{Introduction}

The Tangut manuscript introduced here was found by Kozlov expedition in Khara-khoto and now preserved in the Institute of Oriental Manuscripts, Russian Academy of Sciences, with its inventory number 5875. It was first reported by (GORBACHEVA and KYCHANOV 1963, 24) as Taizu Jiqian Wen 太祖繼遷文 (A book of Jiqian, the First Emperor) and was characterized as a record of some government affairs about the first founder of the Xixia Dynasty, Jiqian (963-1004). The manuscript has not been put into any descriptive catalogue so far because its text seems too difficult to be deciphered. The facsimile of the Tangut original was published with the title Taizong Zeyao Wen 太宗擇要文 (A book of brief collection by Taizong, the Second Emperor). ${ }^{1}$ (NISHIDA 1999, 12) translated the first two sentences

(C) Nie Hongyin, Beijing Normal University, Sichuan Normal University, China, 2020

${ }^{1}$ See Ecang Heishuicheng Wenxian 俄藏黑水城文獻 (Heishuicheng manuscript collected in Russia) vol. 11, p. 112-116, Shanghai: Shanghai Chinese Classics Publishing House, 1999. 
into Japanese and pointed out that the text was by no means related to historical facts about Jiqian, but the nature of the whole booklet remains unknown. Although ten couplets were translated and commented later (NIE 2012), we are still not able to solve the problem completely. Because it has been said that this manuscript is one of the most puzzling texts for Tangutologists to read over, the present paper intends to provide the translations and narrations as more as possible in order to lay a primary foundation for further studies.

The manuscript in question consists of ten folia, fragmentary from the fifth folio on. The first six folia are written in comparatively structured running hand, but the following are in illegible cursive hand. The calligraphic style shows that the original was not transcribed by one and the same person. At the beginning of the booklet there are no colophons by authors or dates, but

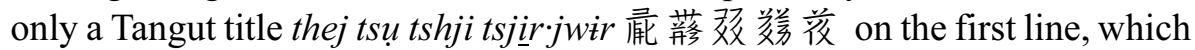
was translated into Chinese by Nishida as Dazu Yaoxuan Wen 大祖要選文 (A book of important collection by the First Emperor). Of course the actual meaning of the title remains unclear to us, but we can definitely say that the Tangut proper noun thej tsu should be translated into Chinese as taizong 太宗 (the Second Emperor), not taizu. We base on the fact that the word thow thej tsu信䨿荊 is used for Emperor Tang Taizong 唐太宗 (598-649) in the Tangut version of the Commentaries of Sunzi's Art of War (LI 1997, 789). Another character needs to be mentioned is jwir 蕧 (writing, book), which is used here as a suffix of book title beyond its lexical meaning, ${ }^{2}$ for this reason we should better translate the title as "Brief Collection by Taizong" (hereafter $\mathrm{BCT})$.

According to the parts I am able to read, it may be said with certainty that the BCT is a compilation inconsistently miscellaneous of ancient literary allusions and contemporary folk maxims. Plentiful ancient Chinese literary allusions show that the text must have been translated from Chinese, but so far nobody have found its Chinese original in any materials available, so we have to work out some tentative reconstruction of the Chinese contents. Needless to say, no matter how we try our best on making the reconstructions closer to the ancient literary style, it is impossible for us to reconstruct the Chinese original exactly, especially to reconstruct the folk maxims.

\footnotetext{
${ }^{2}$ It seems to be a traditional custom that Non-Chinese people take a word of the same usage attached to a book title, e.g., bitig (writing, book) in Uyghurian and bithe (writing, book) in Manchu.
} 


\section{Narrations and translations}

The BCT text begins with emphasizing the importance of sages to assist their rulers, and with two ancient monarchs mentioned. The second one, $x \tilde{a}$

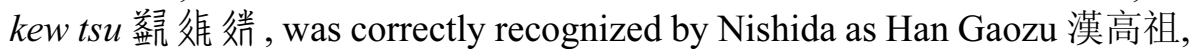
whereas the first one, sju·jã njij 栘効席, was reluctantly translated as a certain yanwang 燕王 with the first character sju unsolved. Now we can assume that the name actually indicates Xu Yanwang 徐偃王, a legendary moral King of the State Xu in the Spring and Autumn Period (770-476 BC.). Here is the relevant couplet (fig. 1):

\section{Folio 1, line 2-3:}

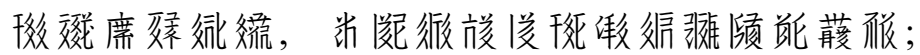

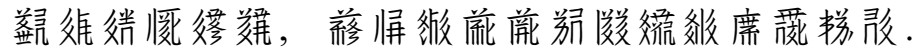

[King $\mathrm{Xu}$ Yanwang possessed kindness and morality, but lost the state for lacking persons as legs and shoulders ${ }^{3}$ at left and right;

Emperor Han Gaozu abandoned institution and politeness, but flourished the imperial power for having ministers as joints ${ }^{4}$ inside and outside.]

Chinese tentative reconstruction:

徐偃王有仁德, 卻無左右股肱之人而國土喪;

漢高祖失禮義, 實有內外肯綮之臣而帝道昌.

The author states that a ruler will not succeed without assistance of eminent ministers around him. The story concerning Xu Yanwang is recorded in chapter 49 of Hanfeizi: ${ }^{5}$

King $\mathrm{Xu}$ Yanwang had his state of five hundred square $l i^{6}$ located in Handong ${ }^{7}$. Because of his kind and polite behavior, 36 states had audiences with him by ceding their territory. King Jing Wenwang ${ }^{8}$, being afraid of

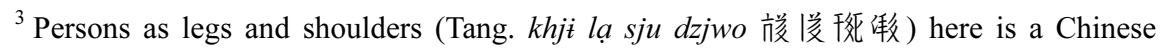
metaphor for indispensable assistants.

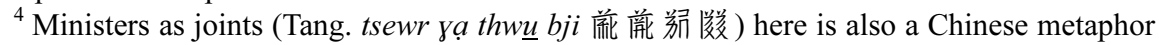
for pivotal assistants.

${ }^{5}$ Chinese original: 徐偃王處漢東, 地方五百里, 行仁義, 割地而朝者三十有六國. 荆文王恐 其害己也, 舉兵伐徐, 遂滅之. 故文王行仁義而王天下, 偃王行仁義而喪其國. (韩非子.五蠹).

${ }^{6} \mathrm{Li}$ is a traditional Chinese unit of measure ( $\approx 400$ meters at that time).

${ }^{7}$ Handong, an ancient name of a certain place, perhaps was located to the east of the Hanshui River, now Hubei Province.

${ }^{8}$ Jing Wenwang, i.e., Chu Wenwang 楚文王 (?-675 BC.), named Zi 貲, was the King of State Chu (now Hunan and Hubei Province), ruling the state from 690 to 675 BC. 
danger to himself, sent troops to attack the State Xu and destroyed it. Therefore King Wenwang ${ }^{9}$ reigned over the world by his kind and polite behavior, while Yanwang lost his state also by his kind and polite behavior.

Han Gaozu indicates the founder of Han Dynasty, Liu Bang 劉邦 (256-195 BC.). As for the story concerning his arrogance, see his biography in volume 8 of Shiji: ${ }^{10}$

The emperor said: "Each nobleman and general dare not hide from me, all tell me the case: What is the reason why I acquire the world? What is the reason why Xiang Yu ${ }^{11}$ loses the world?" Gao Qi and Wang Ling answered: "Your Majesty insults others arrogantly, while Xiang Yu respects others kindly. Your Majesty ordered others to capture cities and territories, then gave them as awards, enjoying the benefits with the world. Xiang Yu did not take this way; he injured heroes, suspected sages. This is the reason why he lost the world".

The subject of the following couplet is not related to the previous one and advises people not to be addicted to gambling games. It mentions two names:

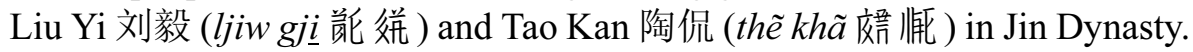

\section{Folio 1, line 3-4:}

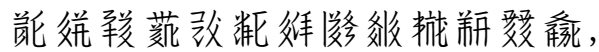

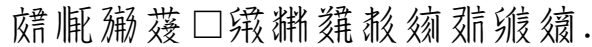

[Liu Yi got a capital crime for concentrating himself on chupu, $^{12}$ Tao Kan distinguished himself for throwing the gambling devices ${ }^{13}$ into river.]

\footnotetext{
${ }^{9}$ Wenwang here indicates Zhou Wenwang 周文王 (approximately 1152-1056 BC.), named 姬昌, the founder of Zhou Dynasty.

${ }^{10}$ Chinese original: 上曰: “列侯, 諸將弗敢隱朕, 皆言其情: 我所以有天下者何? 項氏之所 以失天下者何?”高起, 王陵對曰: “陛下慢而侮人, 項羽仁而敬人. 陛下使人攻城掠地, 因以 與之, 與天下同其利; 項羽不然, 有功者害之, 賢者疑之, 此所以失天下也.” (史記·高祖本紀)

${ }^{11}$ Xiang Yu 項羽 (232-202 BC.), generally called Xichu Bawang 西楚霸王, was a leader of uprising against Qin Dynasty, being defeated by Liu Bang at last.

${ }^{12}$ Chupu 㯪蒱 (Tang. thja wju liu 酸荻改, gamble throwing) is an ancient dice game with five small wood blocks, coloring black on one side and white on the other. According to the combination of different colors, the awards are divided into five grades: The first grade award is called $l u$ 盧 (all black), the second $z h i$ 雉 (pheasant, four black and one white), those beside the two (including heidu 黑凟, black calf) came to nothing.

${ }^{13}$ Gambling device (Tang. khej lhjor 䃄㜇, game table) here might be basin of the dice.
} 
Chinese tentative reconstruction:

劉毅專心㯪蒱而獲死罪,

陶㑆投博江水而美名揚.

Liu Yi (?-412), a general of Song Dynasty in the Southern Dynasties Period, was known for his insolence. He prepared to launch an insurrection against Emperor Wudi (Liu Yu), but was defeated ahead of time. The story may be found from his biography in volume 45 of Jinshu: ${ }^{14}$

After then they gathered together at the eastern mansion for an unrestrained dice gambling with millions of money per game. When others played heidu and went back, only Liu Yu ${ }^{15}$ and Liu Yi left behind. Yi played a $z h i$ and then lifted his clothes and walk around the stool with a great rejoicing, calling Yu to sit together and said: "It is not that I am unable to get a $l u$, merely I do not want to play that." Yu disliked his words, so he grasped the five wood blocks for a long while and said: "As the elder brother, let me answer you." Soon afterwards, four blocks were black but one kept turning. Yu shouted harshly and it immediately became $l u$. Yi felt extremely unpleasant, his face turned as black as iron, but he said calmly: "I already know that you will not coordinate with me!" After he went to the western defense, although he was back to share the responsibility for governing Shan Prefecture, he immediately lost the authority in royal court. Considering his limited transaction and position, he intended to await an opportunity to overturn Yu by his powerful force, but failed at last.

Tao Kan (259-334) was a famous minister and general of the Eastern Jin Dynasty. The relevant story comes from his biography in volume 66 of Jinshu: ${ }^{16}$

Tao Kan was intelligent by nature, diligent in official jobs, courteous and polite, obeying human relations ... Once there were assistants who delayed their affairs by chatting or gambling, he ordered someone to take back their liqueur sets and gambling devices and then throw them into river. General assistants were punished. He said: "Chupu is merely a game for swineherds!"

${ }^{14}$ Chinese original: 後於東府聚㯪蒱大橂, 一判應至數百萬. 余人並黑犢以還, 唯劉裕及 毅在後. 毅次擲得雉, 大喜, 褰衣繞床, 叫謂同坐曰: “非不能盧, 不事此耳.”裕惡之, 因挼五 木久之, 口: “老兄試為卿答.” 既而四子俱黑, 其一子轉躍未定. 裕庽聲喝之, 即成盧焉. 毅 意殊不快, 然素黑, 其面如鐵色焉, 而乃和言曰: “亦知公不能以此見借! ”既出西笽, 雖上 流分陝, 而頓失內權, 又頗自嫌事計, 故欲擅其威強, 伺隙圖裕, 以至於敗. (晋书・刘毅传)

${ }^{15}$ Liu Yu (363-422), i.e., Song Wudi 宋武帝, was the founder of the Song Dynasty in Southern Dynasties Period.

${ }^{16}$ Chinese original: 㑆性聰敏, 勤於吏職, 恭而近禮, 愛好人倫 ... 諸參佐或以談戲廢事 者, 乃命取其酒器蒱博之具, 悉投之于江, 吏將則加鞭撲, 曰: “㯪蒱者, 牧豬奴戲耳!” (晉 書・陶㑆傳). 


\section{8}

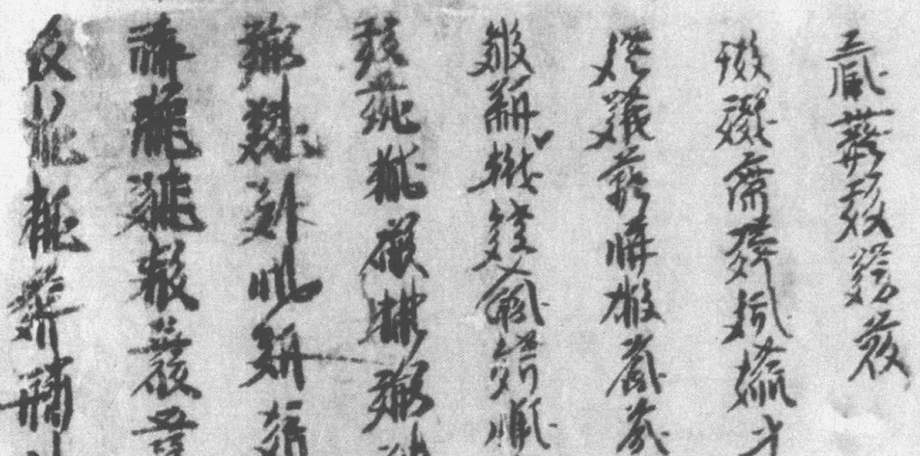

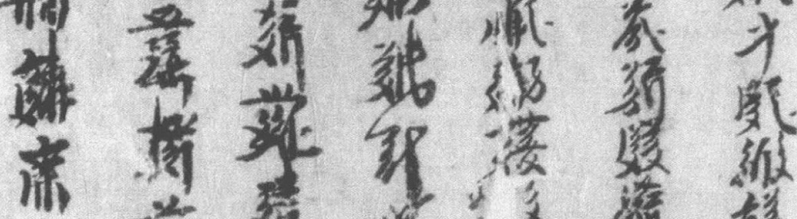

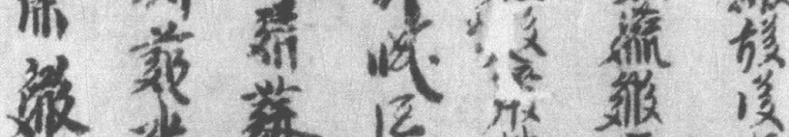

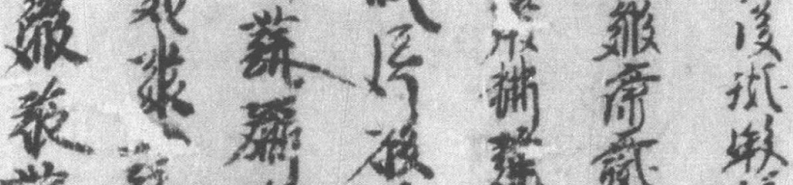

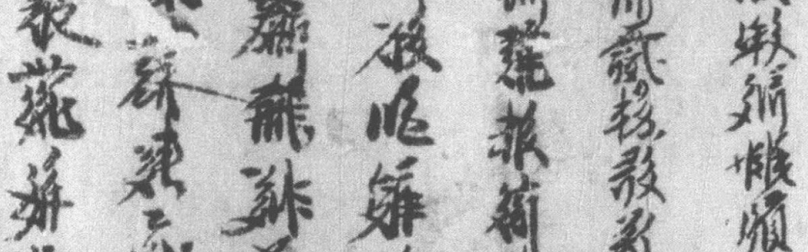

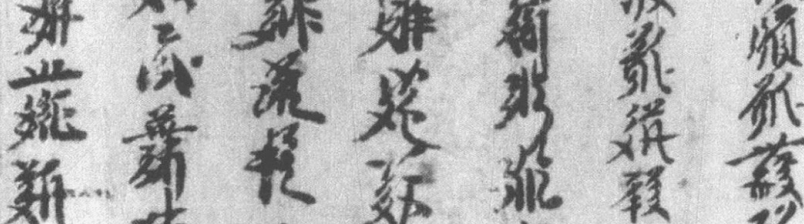

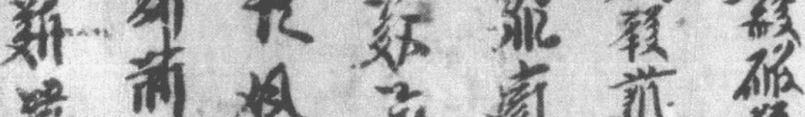

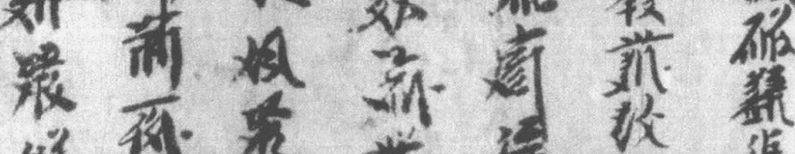

Fig. 1

The first folio of Brief Collection by Taizong 


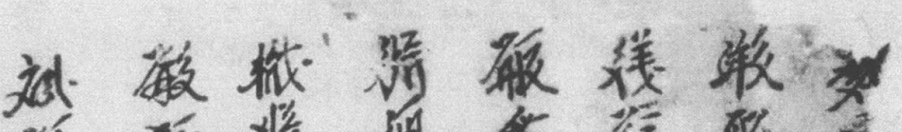

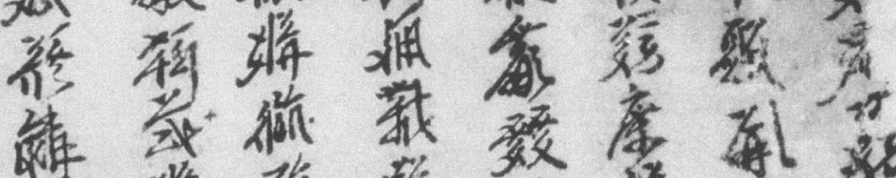

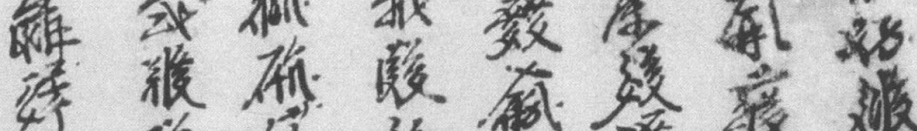

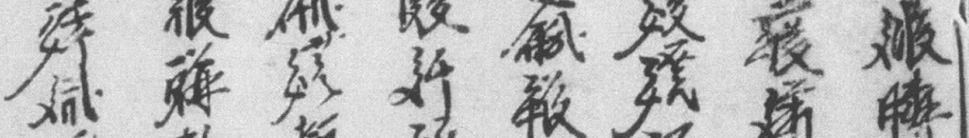

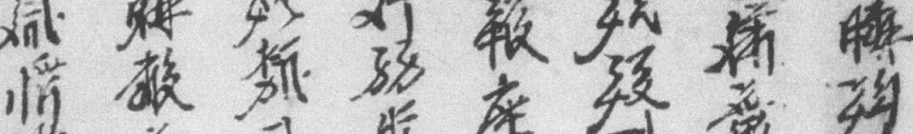

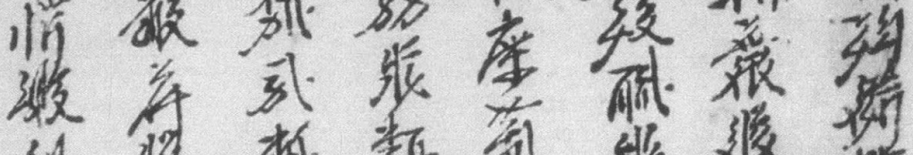

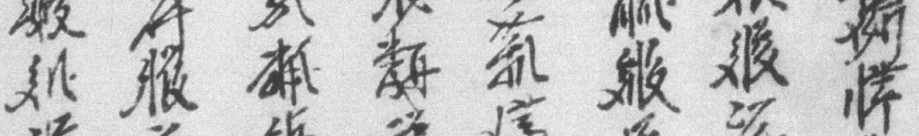

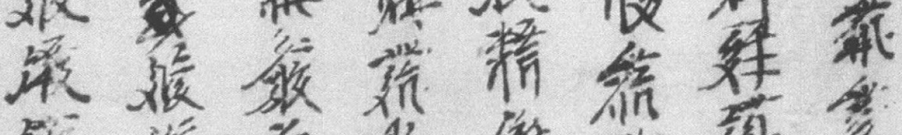

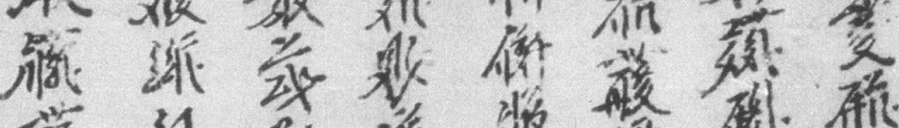

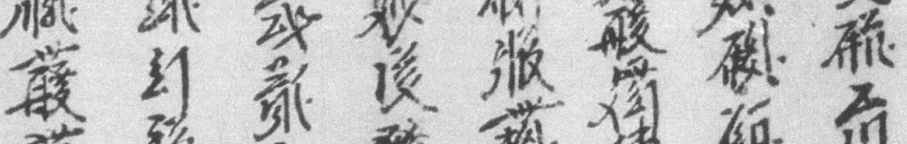

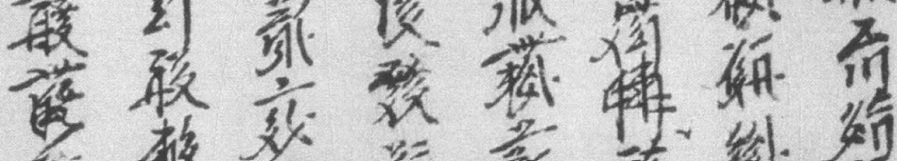

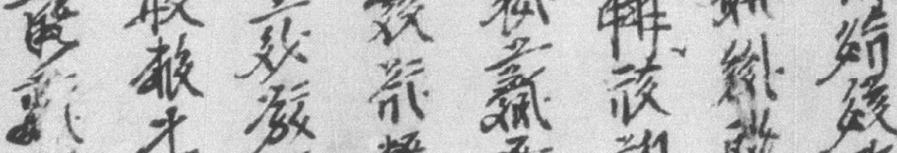

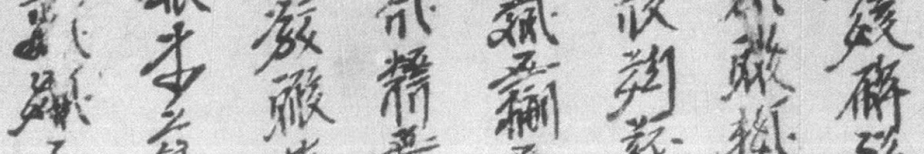

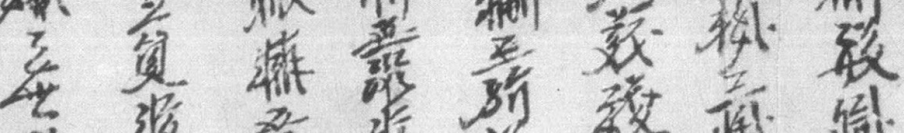

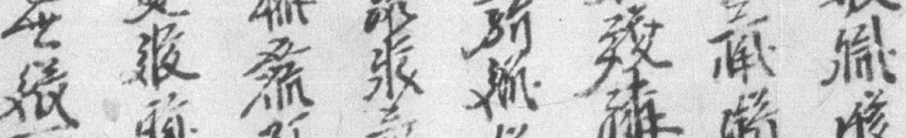

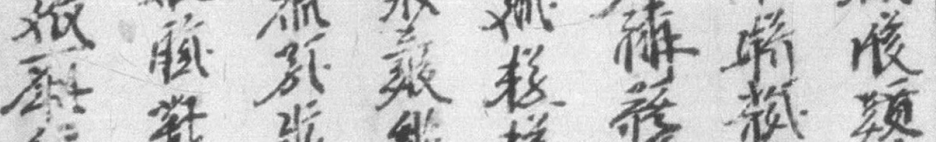

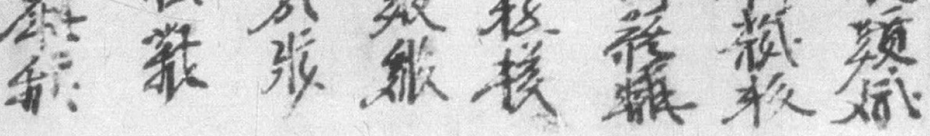

Fig. 2

The second folio of Brief Collection by Taizong 
Many key words in the next three couplets are written so perfunctorily that the characters cannot be recognized one by one. What may be read is a story of a certain person in Jin Dynasty who entertained himself without stop even when his mother was dying. These three couplets are followed by the story of how Emperor Yao 堯 (jiw 废青) examining Shun 舜 (śjwi 腈) to be his successor.

\section{Folio 1, line 8 - Folio 2, line 1 (Fig. 2)}

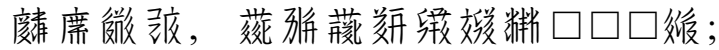

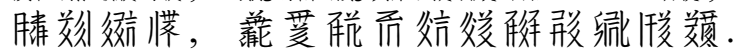

[King Yao got false accusation when Shun collected firewood ${ }^{17}$ and drew water ${ }^{18}$ he harmed ......

Emperor Shun was reported benevolence and selected as a sage when he lifted a flag in pasturage ${ }^{19}$ and fields.]

Chinese tentative reconstruction:

堯王得堍, 塗畐穿井時害 ...

舜帝告善, 巡狩耕田中拔擢智人.

The above narration of Yao and Shun, who were legendary Chinese sage emperors, might have been deduced from the first volume of Shiji, ${ }^{20}$ but with some serious errors caused by the compiler or Tangut translator's misunderstanding of Chinese classics:

Shun ploughed at the Mount Lishan ... Gusou ${ }^{21}$ still wanted to murder him. Gusou ordered Shun to climb up for mending a granary, then he set fire below to burn the granary. Shun protected himself with two bamboo hats, getting down and leaving, so he got survived. After that Gusou ordered Shun to dredge a well, and Shun dug a hiding hole with an exit on a

${ }^{17}$ Tangut sji śji tśhjij kjwi 荻駢荊瓶 (collecting wood and grass = collecting firewood) is the misunderstanding of Chinese tulin 塗廩 (mending a granary).

${ }^{18}$ Tangut zjïr kha 無媛 (drawing water) is the misunderstanding of Chinese chuanjing 穿井 (dredging a well).

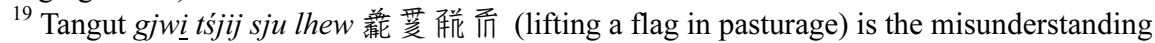
of Chinese xunshou 巡狩 (inspection tour), a rite for an emperor just acceded to the throne.

${ }^{20}$ Chinese original: 舜耕歷山 ... 韾叟尚復欲殺之, 使舜上塗庿, 韾叟從下縱火焚廩. 舜 乃以兩笠自扞而下, 去, 得不死. 後韾叟又使舜穿井, 舜穿井為匿空旁出. 舜既入深, 韾叟與 象共下土實井, 舜從匿空出,去 ... 堯老, 使舜攝行天子政, 巡狩. (史記·五帝本紀).

${ }^{21}$ Gusou, meaning "old blind man", is the name of Shun's father. He disliked Shun and plotted murdering him repeatedly but failed at last. 
side wall. When Shun went deep, Gusou and Xiang ${ }^{22}$ filled in the well with dirt, but Shun went out through the hiding hole and left ... Yao, in his old age, let Shun act temporarily for the government affairs as an Emperor, engaging in an inspection tour.

The following sentences continue the subject of Yao and Shun, in which the stories concern Ji Kang 嵇康 (khji khow 蘐骕), Liang Hong 梁鴻 (ljow xu

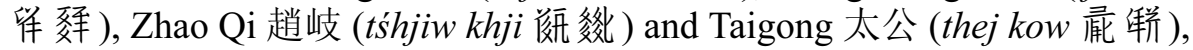
who suffered hard lives before they became famous for their moral qualities.

Folio 2, line 1-2:

行湃副瓶:

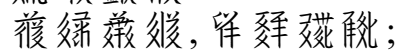

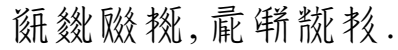

[Moral persons sought benefit: ${ }^{23}$

Ji Kang hammered iron, Liang Hong was employed for pounding grain;

Zhao Qi sold pancakes, Taigong sold flour.]

Chinese tentative reconstruction:

德者尋利:

嵇康鍛鐵, 梁䲨賃春;

趙岐販餅, 太公賣麵.

Ji Kang (224-263), as an outstanding ideologist and literati in the Wei-Jin Period, was one of the famous "Seven sages in bamboo grove" (Chin. zhulin qixian 竹林七賢) and the founder of the Metaphysic School. His anthology has been preserved till nowadays. The story of hammering iron comes from his biography in volume 49 of Jinshu: ${ }^{24}$

Ji Kang, living a poor life in his early years, hammered iron for self-supporting together with Xiang $\mathrm{Xiu}^{25}$ under a big tree. Zhong $\mathrm{Hui}^{26}$ from the Yingchuan Prefecture, a noble junior of keen-witted competence and talented eloquence, went to meet him. Kang did not receive him politely and hammered without stop.

\footnotetext{
${ }^{22}$ Xiang was the younger son of Gusou and was indulgent by his father.

23 “Seeking benefit” (Tang. gjij ju 賟㔙) here means “finding some way to support one's life".

${ }^{24}$ Chinese original: 初, 康居貧, 嘗與向秀共鍛於大樹之下, 以自贍給. 穎川鍾會, 貴公子 也, 精練有才辯,故往造焉. 康不為之禮, 而鍛不輟. (晉書·嵇康傳).

${ }^{25}$ Xiang Xiu (approximately 227-272), a literati in the Wei-Jin Period, was one of the famous "Seven sages in bamboo grove" in accompany with Ji Kang.

${ }^{26}$ Zhong Hui was a famous minister in State Wei of the Three Kingdom Period, one of the chief commanders in the war to destroy State Shu.
} 
Liang Hong, lived in the 1st c. AD, was a poor hermit in the Eastern Han times and became famous with his wife through the idiom ju an qi mei 舉案 齊眉 (raising a serving table to brow). The story of pounding grain comes from his biography in volume 83 of Houhanshu: ${ }^{27}$

Liang Hong then arrived to $\mathrm{Wu}$ Prefecture and served to a rich man Gao Botong, living at a side room and being employed for pounding grain. Whenever back at home, his wife prepared food for him by raising a serving table up to her brow and dared not look up in front of him. Botong found this with a surprise and said: "That servant should not be an ordinary person because he makes his wife to respect him like this." Thus he let Hong live in the main house.

Zhao Qi 趙岐 (?-201), also written Zhao Qi 趙歧, a scholar at the end of the Eastern Han Period, was framed and had to leave his official position to a remote area where he wrote his famous commentaries to Mencius. The relevant story may be found in his biography in volume 64 of Houhanshu: ${ }^{28}$

At the end of Han Dynasty, Zhao Qi went to Hejian Prefecture escaping from calamity, where nobody knew his name. Then migrating to Beihai Prefecture, he often wore a cotton trouser to sell pancakes at the market. Sun Binshuo ${ }^{29}$, in his twenties at that time, entered the market in an oxcart and accompanied by two guardsmen on horse. Seeing Qi, he expected that he was not an ordinary person, and asked him: "Are the pancakes cooked by yourself?" Qi said: "I resell them." Binshuo said: "For how much money do you buy it? For how much money do you sell it?" Qi said: "Thirty for buying, also thirty for selling." Binshuo said: "Your intellectual feature shows me that you are not a pancake seller. There might be a reason." Then he opened the back door of the cart and turned back to the two guardsmen, ordering them to get down from their horses and help Qi to get on the cart.

Taigong, i.e., Jiang Taigong 姜太公 (approximately 1156-1017 BC.), named Lü Shang 吕尚 or Lü Wang 吕望, also called Taigong Wang 太公望, was an outstanding politician and strategist who directed Emperor Zhou

${ }^{27}$ Chinese original: 梁鴻 ...... 後至吳, 依大家臬伯通, 居应下, 為人賃春. 每歸, 妻為具 食, 不敢於鴻前仰視, 舉案齊眉. 伯通察而異之, 曰: “彼傭以使其妻敬之如此, 非凡人也.” 乃方舍之於家. (後漢書·梁鴻傳).

${ }^{28}$ Chinese original: 漢末, 趙歧避難逃之河間, 不知姓字. 又轉詣北海, 著絮巾褲, 常於市 中販胡餅. 孫賓碩時年二十餘, 乘犢車將騎入市, 觀見歧, 疑其非常人也, 因問之: “自有餅 耶?”歧曰: “販之.”賓碩曰: “買幾錢? 賣幾錢?”歧曰: “買三十, 賣亦三十.”賓碩曰: “視處士 之望, 非買餅者, 殆有故.” 乃開車後戶, 顧所將兩騎, 令下馬扶上之. (後漢書·趙歧傳).

${ }^{29}$ Sun Binshuo, active in the second half of the 2 nd c., was the governor of the prefecture where he made a close friendship with Zhao Qi. 
Wuwang to overthrow Shang Dynasty thus became the founding father of Zhou Dynasty. As for the legend of his early years, we can only find the reference in two commentaries of Shiji. one is attached to the text "Lü Shang was trapped in Jijin" (Lü Shang kun yu Jijin 呂尚困於棘津) by Zhang Shoujie 張守節 in volume $124::^{30}$

Taigong Wang sold foods in Jijin in nearly seventy years of age.

“Selling foods in Jijin” was recorded by Sima Zhen 司馬貞 as “selling drinks in Mengjin"31 in his commentary to "Lü Shang was already poor and old at that time” (Lü Shang gaichang qiongkun nianlaoyi 呂尚蓋嘗窮困年老矣) in volume 32 of Shiji. It is noticeable that the canonical histories only mentioned selling foods or drinks but not "selling flour". The story of Taigong selling flour is widely spread among the people nowadays might be deduced by later generations. ${ }^{32}$

The following couplet says that farming should be the basis for rulers in governing a country. Three names are mentioned there: Lu Xigong 魯僖公 (luxji njij 绕经席), Shun舜 (sjjwi 膦) and $\mathrm{Yu}$ 禹 (giu 㸚).

\section{Folio 2, line 3-4:}

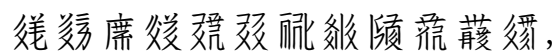

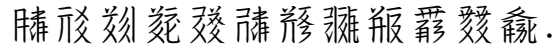

[That King Lu Xigong ${ }^{33}$ engaged in farming led the state abundant, That Emperor Shun and Yu based on agriculture led the masses peaceful.] Chinese tentative reconstruction:

魯僖公務稼穡而國阜, 舜禹帝本農耕而民安.

Lu Xigong (?-627 BC.), named Ji Shen 姬申, was the 18th monarch of State $\mathrm{Lu}$ in the Spring and Autumn Period, reigning for 33 years. The relevant story comes from chapter The 21st year of Xigong in Zuozhuan: ${ }^{34}$

\footnotetext{
${ }^{30}$ Chinese original: 太公望行年七十, 賣食棘津云. (史記正義·游俠列傳).

${ }^{31}$ Chinese original: 賣飲於孟津. (史记索隐·齐太公世家).

${ }^{32}$ An untraceable folk legend said that Taigong was extremely unlucky in his early years. When he sold flour, wind blew his flour away; when he sold salt, rain melted his salt away.

${ }^{33}$ Tangut njij 席 (king) is used here to render Chinese gong 公 (Duke), because Tanguts had not the conception of Five Titles for Nobles (gong 公, hou 侯, bo 伯, $z i$ 子, nan 男) of Pre-Qin Period. Of course it will be better if the Tangut phonetic transcription kow 任 is used in Huangong 桓公 as shown below.

${ }^{34}$ Chinese original: 夏, 大旱. 公欲焚巫廷. 臓文仲曰: “非旱備也. 修城郭, 貶食省用, 務 穡勸分, 此其務也.巫王何為? 天欲殺之, 則如勿生; 若能為旱, 焚之滋甚.”公從之. 是歲也, 饑而不害. (左傳·僖公二十一年).
} 
There was a bad drought in summer. The King intended to burn down a witch Wang. ${ }^{35}$ Zang Wenzhong ${ }^{36}$ said: "This is not the way for restraining drought. What should be done is to mend city walls, economize foods and expenses, engage farming and advise to alms. What use is it to burn down a witch Wang? If the Heaven intends to kill the masses, they should not be born; if a witch can bring drought, things should be even worse after burning her down." The King followed his expostulation. That year there was poor harvest but not disastrous.

Shun, as one of the ancient "Five Emperors" in legend, was venerated as the originator of morality in China. The story of his farming can be seen in the first volume of Shiji: ${ }^{37}$

When Shun ploughed at the Mount Lishan, all people at Lishan vacated their field boundaries; when he fished on the Lake Leize, all people on Leize vacated their locations; when he made potteries beside river, there were not any defective items beside the river. His residence became a village in the first year, became a town in the second year and became a metropolis in the third year.

Yu was the founder of Xia Dynasty, being famous for his taming the flood and establishing the institution of the Nine Administrative Divisions (Chin. Jiuzhou 九州). The story of his farming can be seen in Chapter 14 of Quotations of Confucius: ${ }^{38}$

$\mathrm{Yi}^{39}$ was good at archery, $\mathrm{Ao}^{40}$ was good at punting, but both of them did not die a natural death. Yu and $\mathrm{Ji}^{41}$ obtained the whole world by farming personally.

The following subject turns to liquor commandments, in which the two names are mentioned Zifan 子反 (tsuxiwã 䊔裓) and Bi Zhuo 畢卓 (pji tśiow 㣔邪).

\footnotetext{
${ }^{35}$ Burning somebody to death is a method to prevent disasters in ancient China.

${ }^{36}$ Zang Wenzhong (?-617 BC.) was an enlightened minister assisting four monarchs of State Lu.

${ }^{37}$ Chinese original: 舜耕歷山, 歷山之人皆讓畔; 漁雷澤, 雷澤上人皆讓居; 陶河濱, 河濱 器皆不苦窊. 一年而所居成聚, 二年成邑, 三年成都. (史記・五帝本紀).

${ }^{38}$ Chinese original: 羿善射, 悬蕩舟, 俱不得其死然. 禹稷躬稼而有天下. (論語・憲問).

${ }^{39} \mathrm{Yi}$, usually called Hou Yi 后羿 (King Yi), was a legendary hero in archaic times. As a skillful archer, he shot down nine of the ten suns in severe heat weather but was killed by his apprentice at last.

${ }^{40}$ Ao was a legendary figure in Xia Dynasty. He was able to punt a boat on the ground with his unusual strength, but at last was killed by the seventh generation from Yu.

${ }^{41} \mathrm{Ji}$ 稷, usually called Hou Ji 后稷 (King Ji), was venerated as the ancestor of farming and the deity of grains in Chinese legend.
} 


\section{Folio 2, line 4-5:}

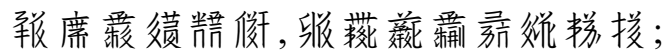

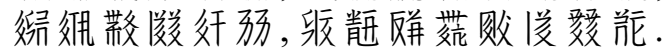

[General Zifan of the King of State Chu killed himself for being drunken by accident and being defeated;

Minister Bi Zhuo of Jin Dynasty was captured for stealing liquor when he was drinking excessively.]

Chinese tentative reconstruction:

楚將子反, 誤醉戰敗而自盡;

晉臣畢卓, 盜酒造飲以遭擒.

Zifan (?-575 BC.), named Ce 側, was the commander in chief of the troops of State Chu in the Spring and Autumn Period. His story of drinking comes from chapter The 16th year of Chenggong in Zuozhuan: ${ }^{42}$

Guyang $\mathrm{Shu}^{43}$ offered liquor to Zifan, Zifan was drunk and could not meet the King. The King said: "The Heaven will destroy the State Chu. I cannot stay here." Then he fled at night ... When the troops went back to Xia, the King ordered someone to tell Zifan: "Earlier you, my senior minister, lost the troops because the King was absent. Please do not think it as your fault, it is my guilt." Zifan saluted twice and said: "If the king grants death to a minister, he will be immortal. My soldiers really fled, it is my guilt." Zizhong ${ }^{44}$ told Zifan: "It is already known that you lost your troops before. Why do not you find some way?" Zifan answered: "Although there were few ministers doing so before, as a minister assisting the King, how dare I do anything injustice? A minister lost the King's troops, how dare I escape the death?" The King ordered somebody to stop him, but he died before the messenger's arrival.

\footnotetext{
${ }^{42}$ Chinese original: 谷陽豎獻飲於子反, 子反醉而不能見. 王曰: “天敗楚也夫! 余不可以 待.” 乃宵遁 ...楚師還, 及瑕, 王使謂子反曰: “先大夫之覆師徒者, 君不在. 子無以為過, 不 穀之罪也.”子反再拜稽首曰: “君賜臣死, 死且不朽. 臣之卒實奔, 臣之罪也.” 子重復謂子 反曰: “初隕師徒者, 而亦聞之矣! 盍圖之?” 對曰: “雖微先大夫有之, 大夫命側, 側敢不義? 側亡君師, 敢忘其死?”王使止之, 弗及而卒. (左传・成公十六年).

${ }^{43}$ Guyang Shu, named Guyang, was a close servant of Zifan. The word $s h u$ 豎 (mean guy) is a derogatory term attached by traditional historians for his entrapping the host by liquor.

${ }^{44}$ Zizhong (?-570 BC.), named Yingqi 嬰齊, Zifan's brother, was also a minister in State Chu.
} 
Bi Zhuo, lived in the first part of the $4^{\text {th }}$ century, was an officer in Ministry of Personnel in the Eastern Jin Dynasty, being famous for delaying his jobs by drinking. The story of his stealing liquor may be found in volume 49 of Jinshu: $:^{45}$

Bi Zhuo, as an official in the Ministry of Personnel, often postponed official jobs by drinking wine. A neighbor official brewed wine, drunken Zhuo went among the jars at night to steal and drink it, but was caught by wine guards. Next morning, when the guards had found that it was Bi from the Ministry of Personal, the guards unbundled him hastily. Then Zhuo led the host to drink beside the jars, and after that he became drunken and left home.

The next two stories, essentially showing the uninhibited life of intellectuals in Wei-Jin Period, seem to be lend for liquor commandments here, in which the second person name mentioned is undoubtedly Liu Ling 劉伶

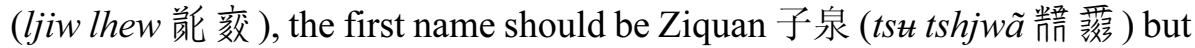
the second character was written as $t o$ 蕧 by a slip of pen. ${ }^{46}$

\section{Folio 2, line 5-7:}

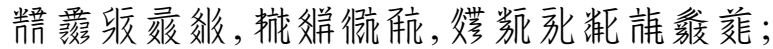

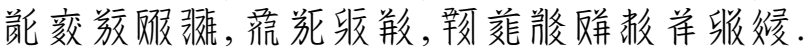

[Ziquan was fond of wine, intending to be buried beside a pottery workshop on deathbed.

Liu Ling liked deer, finding wine in a rich family and one $h u^{47}$ per drinking was insufficient.]

Chinese tentative reconstruction:

子泉嗜酒, 臨卒彌留, 願葬陶家之側;

劉伶好鹿, 尋酒富家, 一斛一飲解酲.

Ziquan, generally called by his surname Zheng Quan 鄭泉 (tśhjij tshjwã 荊蓤) in the Tangut version Forrest of Categories (SHI ET.AL. 1993, 183), was a minister Taizhong Dafu 太中大夫 of State Wu in the Three Kingdoms

\footnotetext{
${ }^{45}$ Chinese original: 卓... 為吏部郎, 常飲酒廢職. 比舍郎釀熟, 卓因醉夜至其甕間盜飲 之, 為掌酒者所縛, 明旦視之, 乃畢吏部也, 遽釋其縛. 卓遂引主人宴於隹側, 致醉而去. (晉書・畢卓傳).

${ }^{46}$ Tangut to 後 is never used for phonetic transcription.

${ }^{47} \mathrm{Hu}$ 斛 is an ancient Chinese unit of measure ( $\approx 20$ liters $)$.
} 
Period. He was often sent to State Shu as an envoy for negotiation but merely being famous as a liquor mania. His story comes from Wushu 吳書 quoted by Pei Songzhi 裴松之 in his commentary attached to "Zheng Quan interviewed Liu Bei in Baidi City” (Zheng Quan pin Liu Bei yu Baidi 鄭泉聘劉備於白帝) in volume 47 of Sanguo Zhi: ${ }^{48}$

Zheng Quan, a given name Wenyuan, from Chenjun Prefecture, was erudite and unusually ambitious but fond of liquor in nature ... On his deathbed, Quan told his relatives: "Do bury me beside a pottery workshop. Maybe I shall turn into soil after one hundred years and fortunately be taken for making wine jars. So it will really satisfy my heart."

Liu Ling lived in the 3rd c. and was one of the "Seven sages in bamboo grove", being famous for his uninhibited attitude to reclusion. The well known story of him comes from volume 49 of Jinshu: ${ }^{49}$

Liu Ling ... often travelled on a deer cart with a pot of wine and ordered someone to follow him with a spade, telling: "Bury me if I die." $\mathrm{He}$ disregarded his body like this. Once he was very thirsty and asked his wife for wine. His wife poured out wine and destroyed the drinking set, admonishing with tears: "Drinking too much is not the way for keeping health. You must quit it down." Ling said: "Well, but I cannot quit it by myself except giving an oath to ghosts and gods. So you may prepare wine and meat." His wife obeyed him. Ling kneeled down and prayed: "Liu Ling is well-known for drinking by nature. One $h u$ per drinking and five $d o u^{50}$ is insufficient. Be careful, women's words can never be obeyed." Then he took wine and meat, and was drunken highly again.

The following subject emphasizes that natural disaster cannot be withstood merely by a king's ability and morality. Two names are mentioned there: Tang 湯 (thow 很) and Yao 堯 (jiw 废䊇).

\footnotetext{
${ }^{48}$ Chinese original: 鄭泉字文淵, 陳郡人. 博學有奇志, 而性嗜酒……泉臨卒, 謂同類曰: “必葬我陶家之側,庶百歲之後化而成土，幸見取為酒壼，實獲我心矣.” (三國志・吳主 傳注)

${ }^{49}$ Chinese original: 劉伶 ...... 常乘鹿車, 攜一壳酒, 使人荷鍤而隨之, 謂曰: “死便埋我.” 其遺形骸如此. 嘗渴甚, 求酒於其妻. 妻捐酒毀器, 涕泣諫曰: “君酒太過, 非攝生之道, 必宜 斷之.” 伶曰: “善! 吾不能自禁, 惟當祝鬼神自誓耳. 便可具酒肉.”妻從之. 伶䟜祝曰: “天生 劉伶, 以酒為名. 一飲一斛, 五斗解酲. 婦兒之言, 慎不可聽.”仍引酒御肉, 隗然復醉. (育書・劉伶傳).

${ }^{50} \mathrm{Dou}$ 斗 is an ancient Chinese unit of measure ( $\approx 2$ liters).
} 
Folio 2, line 7-8:

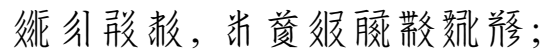

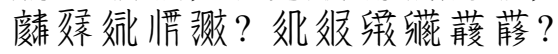

[Emperor Tang had sagacity, but there was seven years drought.

Was not Emperor Yao virtuous? Why there was nine years flooding?]

Chinese tentative reconstruction:

湯有睿智, 卻為七年大旱;

堯非仁德？何泛九載洪災?

Evidently the above couplet is derived from a famous statement by a Han minister Chao Cuo 昆錯 (200-154 BC.) in volume 24 of Hanshu: ${ }^{51}$

The reason why there were not starvations during nine years flooding in Emperor Yao or Yu's times and seven years drought in Emperor Tang's times is that there were lots of accumulations and prearranged preparations.

It is inexplicable that in a few parts of BCT there are not any stories of the ancients and their literary style are not consistent with the context. Obviously these statements are not historical quotations, but folk maxims which are irrelevant with the subject and their sources cannot be found in any traditional Chinese records. It is reasonable to suspect that these couplets might not have come from traditional classics, but blends inserted by later authors or transcribers. The following couplet is a metaphor to emphasize that hard environment helps one to be strong and comfortable condition makes one to be weak.

Folio 2, line 8 - Folio 3, line 2: (Fig. 3)

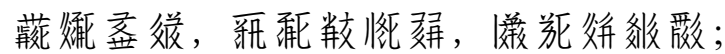

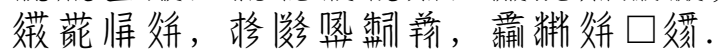

[The branches of a pine at bottom of the valley are not withered in cold, because the growing place makes it forceful;

The leaves of a willow in the garden fall of meeting dew, ${ }^{52}$ because the planting place results it in failure.]

\footnotetext{
${ }^{51}$ Chinese original: 堯禹有九年之水, 湯有七年之早, 而國無捐㾑者, 以畜積多而備先具 也. (漢書・食貨志下).

${ }^{52}$ According to the common sense, here the word "dew" (Tang. war 柊) might be a miswritten “frost” (Tang. nja 唚).
} 
Chinese reconstruction:

松生润底, 經寒枝不枯, 植強處之故;

柳植園中, 露霜葉即落, 植敗處之故.

This topic is objected in the next couplet, where the support from the bigwigs is regarded as the essential condition for succeeding.

\section{Folio 3, line 2-3:}

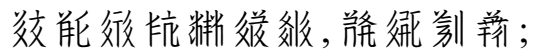

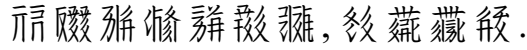

[Growing in dung, the flowers of hibiscus ${ }^{53}$ bloom in the morning and fall in the evening;

Growing in front of a palace, the mingjian grass $^{54}$ blooms in one day and wither after a month.]

Chinese tentative reconstruction:

木蓮花糞中生, 故朝開夕落,

明見草殿前長，故日放月枯。

The next subject turns unaccountably to calling for humility:

\section{Folio 3, line 3:}

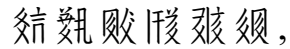

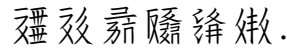

[A virtuous man will be excellent when praised by others, A beautiful woman will be ugly if boasting herself. ]

Chinese tentative reconstruction:

男行人譽則妙, 女美自誇則醜.

\footnotetext{
${ }^{53}$ The flowers of hibiscus (Chin. mulian 木蓮 or mufurong 木芙蓉) bloom only for a very short time, but I do not know whether ancient people believed that they grow in dung.

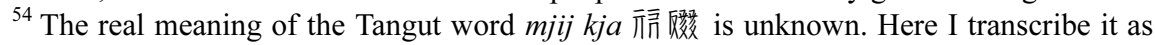
mingjian phonetically because in China it was a sort of grass used for flowering lawn. Perhaps people think that it may be planted on the ground in front of a mansion.
} 


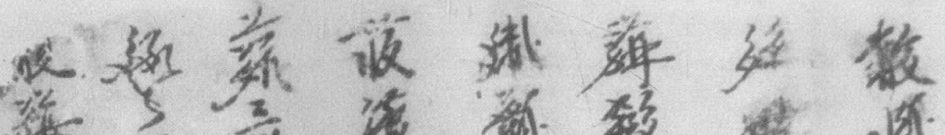

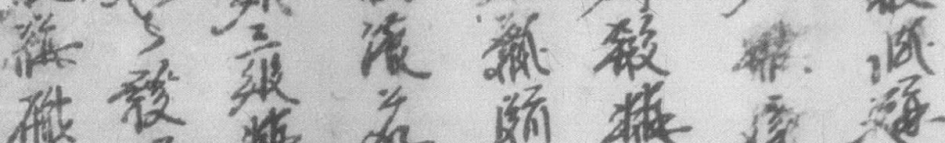

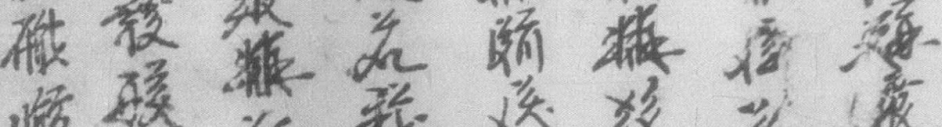

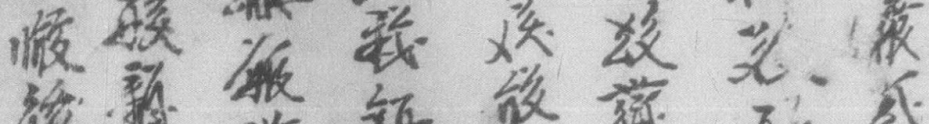

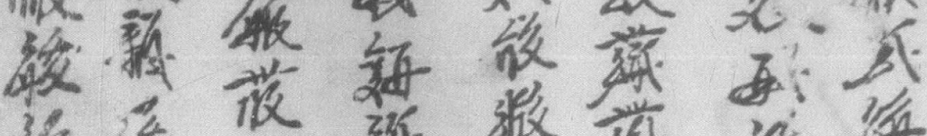

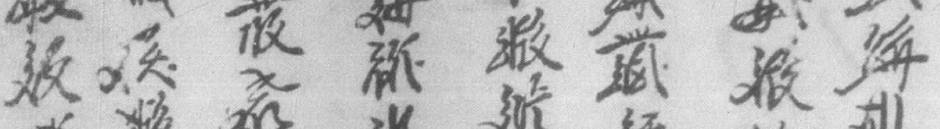

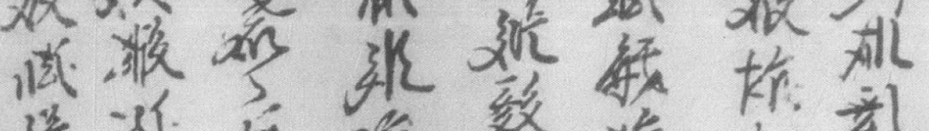

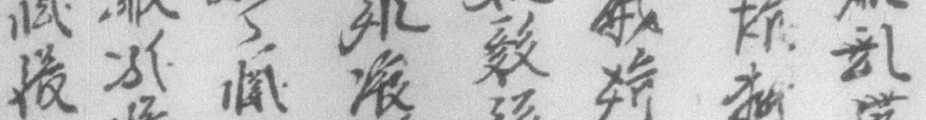

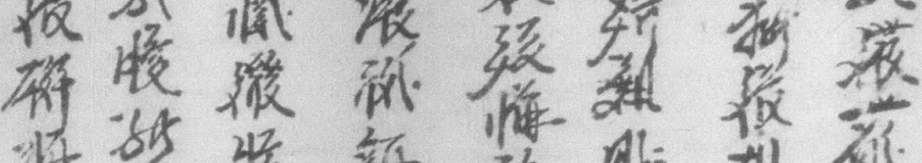

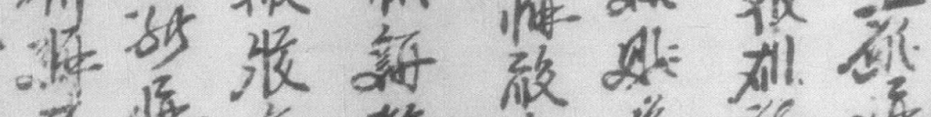

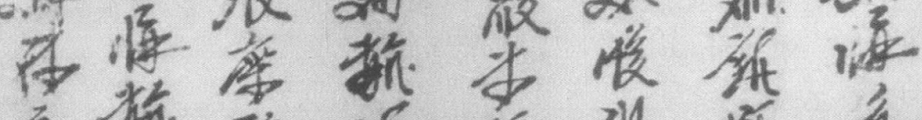

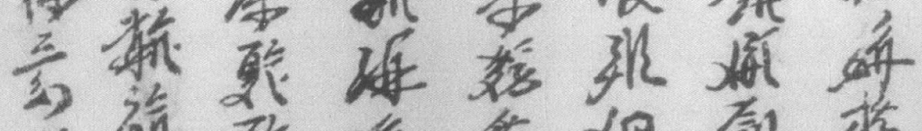

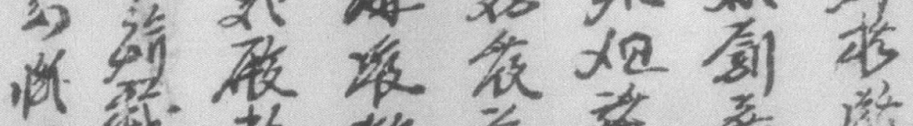

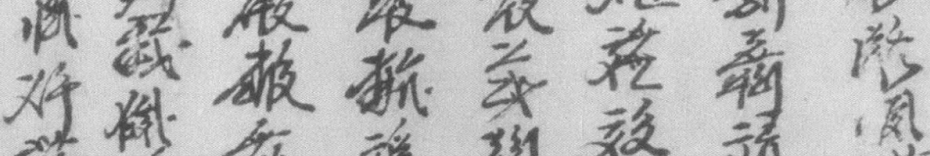

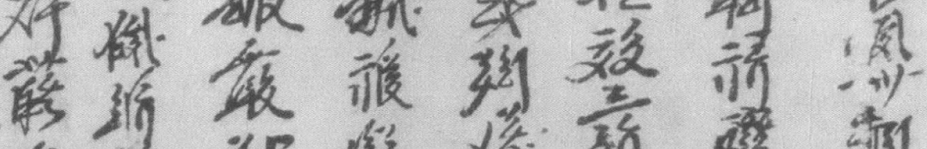

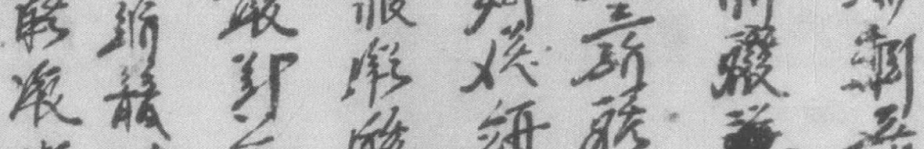

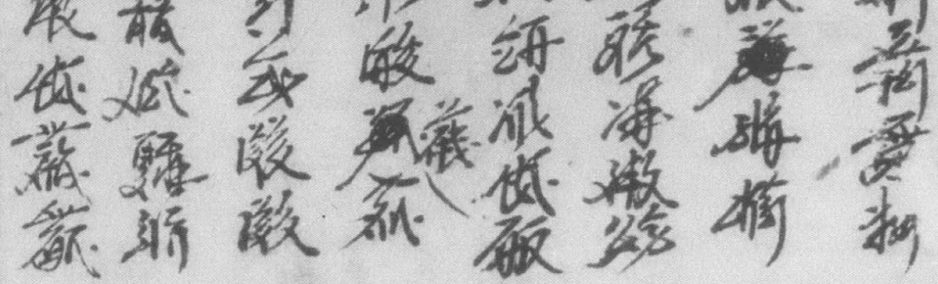

Fig. 3 


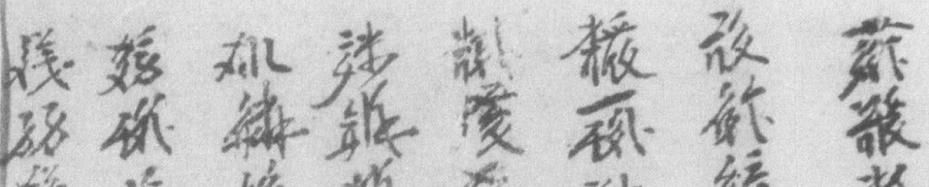

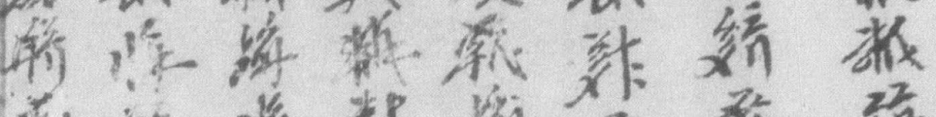

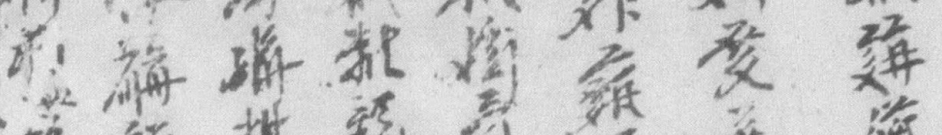

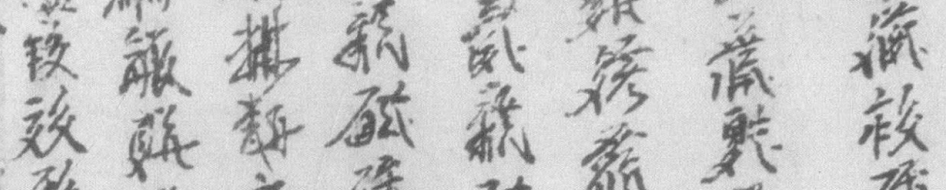

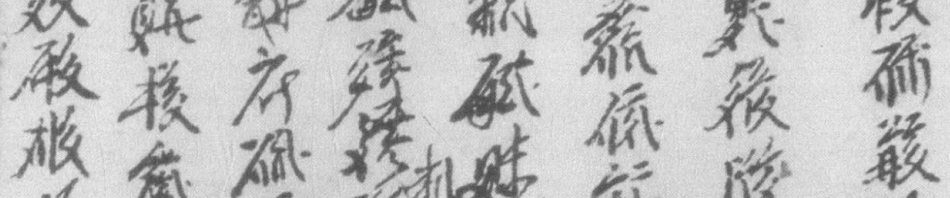

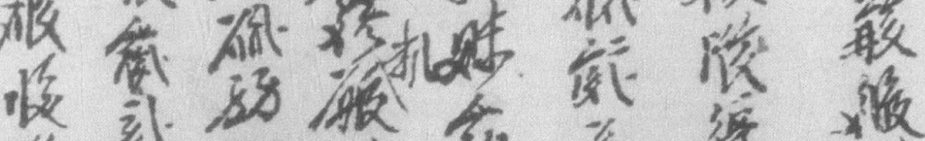

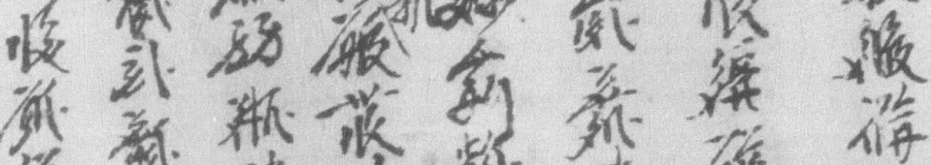

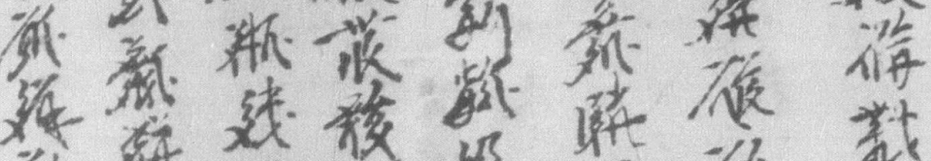

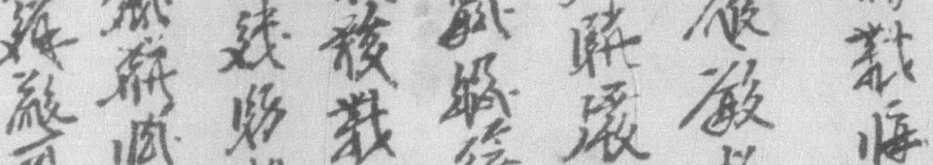

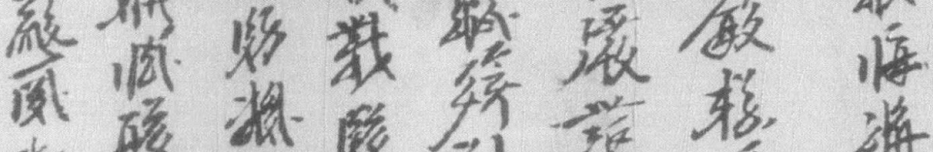

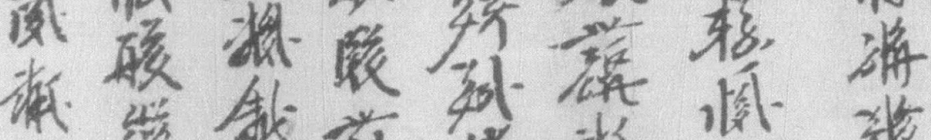

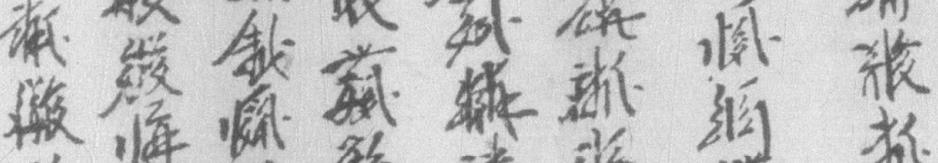

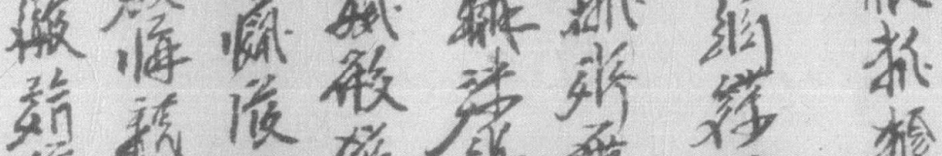

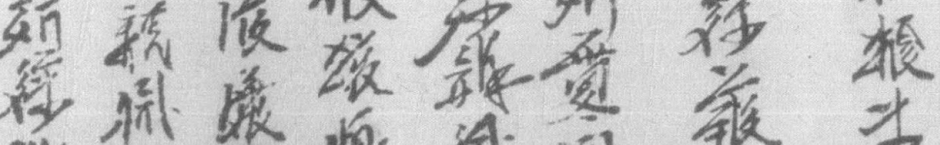

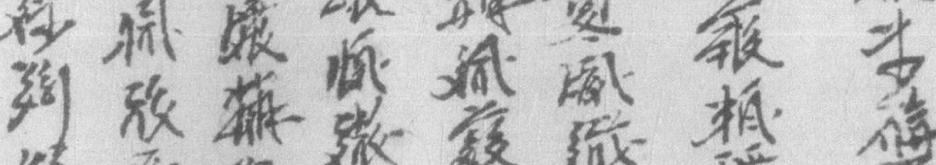

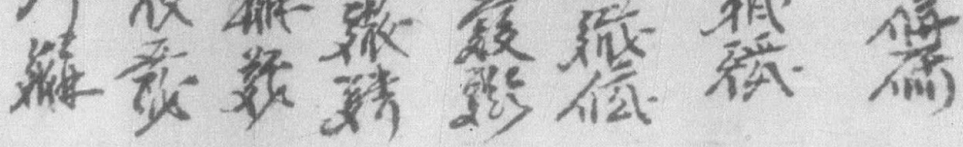

Fig. 4

The fourth folio of Brief Collection by Taizong 
The following couplet turns back to the previous style, which tells the stories of civilians how to catch an eye of noblemen and get promoted. Two persons are mentioned: Feng Xuan 馮諼 (xjow xjwã 父方娆) and Ning Qi 蜜戚 (njij tshji 效教).

Folio 3, line 3-4:

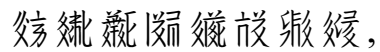

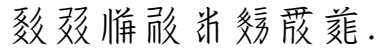

[Feng Xuan claimed necessities by rapping on the sword,

Ning Qi hoped to be interviewed by knocking an ox horn.]

Chinese tentative reconstruction:

馮諼彈鋏以望所需,

蜜戚擊角而求得見.

Feng Xuan, also written Feng Huan 馮驩, was a sponger (Chin. shike 食客) of Mengchang Jun ${ }^{55}$ during the Warring States Period. He excessively asked for many privileges, but helped his host a lot with prestige and political safety. The relevant story comes from volume 11 of Zhanguo Ce: $:^{56}$

There was a man in State Qi, Feng Xuan, poor and not able to support himself. He asked someone to entrust Mengchang Jun for allowing him to be a house guest. Mengchang Jun asked: "What is the guest good at?" He said: "The guest is good at nothing." Menchang asked: "What he can do? He said: "He can do nothing". Mengchang Jun received him with a smile and said: "Well." People around thought that Mengchang Jun looked at him as worthless and then gave him poor food. After some time, Feng Xuan leaned to a column and rapped his sword, singing: "Long scabbard, let us

${ }^{55}$ Tian Wen 田文 (?-279 BC.), titled Mengchang Jun (Viscount Mengchang), was a nobleman in State Qi. As one of the "Four lords of the Warring States period", he was famous for adopting talents, and then became the Prime Minister of the State Qi and Wei in succession but was out of political jam at last.

${ }^{56}$ Chinese original: 齊人有馮諼者, 貧乏不能自存, 使人屬孟嘗君, 願寄食門下. 孟嘗君 曰: “客何好?”曰: “客無好也.”曰: “客何能?”曰: “客無能也.”孟嘗君笑而受之曰: “諾.”左 右以君賤之也, 食以草具. 居有頃, 倚柱彈其劍, 歌曰: “長鋏歸來乎! 食無魚.”左右以告. 孟 嘗君曰: “食之, 比門下之客.”居有頃, 復彈其鋏, 歌曰: “長鋏歸來乎! 出無車.”左右皆笑之, 以告. 孟嘗君曰: “為之駕, 比門下之車客.” 於是乘其車, 揭其劍, 過其友曰: “孟嘗君客我.” 後有頃, 復彈其劍鋏, 歌曰: “長鋏歸來乎! 無以為家.” 左右皆惡之, 以為貪而不知足. 孟嘗 君問: “馮公有親乎?”對曰: “有老母.”孟嘗君使人給其食用, 無使乏. 於是馮諼不復歌. (戰國策・齊策四). 
leave! There is no fish for eating." People around reported that. Mengchang Jun said: "Give him fish, as to guests in my place." After some time, Feng Xuan rapped his scabbard again and sang: "Long scabbard, let us leave! There is no cart for going out." All people around laughed at him and reported that. Mengchang Jun said: "Give him a cart, as to guests in my place." Thereafter Feng Xuan raised his sword in the cart and met his friend, saying: "Mengchang Jun treated me as a guest." After some time, he rapped his scabbard again and sang: "Long scabbard, let us leave! There is nothing to support my family." All people around hated him for his greed and insatiate demands. Mengchang Jun asked: "Has Mister Feng relatives?" They answered: "He has an old mother." Mengchang Jun ordered someone to support her accommodation. Thereupon Feng Xuan did not sing again.

Ning Qi in the Spring and Autumn Period, lived in the second half of the 7th c. BC., was frustrated in his early years but became one of the major ministers and finally assisting King Qi Huangong ${ }^{57}$ The story comes from volume 5 of Xinxu: ${ }^{.8}$

Ning Qi fed an ox under the hackery, feeling grief when catching sight of Huangong. Then he knocked the ox horn and immediately sang a song of Shang. ${ }^{59}$ Huangong heard him and grasped his servant's hand, saying: "I am so amazed that the singer must not be an ordinary person!" Huangong ordered the cart behind to carry him back. The servant asked for instruction, Huangong said: "Give him clothes and hat, I shall interview him." Ning Qi was then interviewed and talked to Huangong how to govern within the border. When being interviewed the next day, Ning Qi talked to Huangong how to possess the world. Huangong was particularly pleased and willing to promote him.

There are not any stories in the following sentences, which merely tell the restraint and leadership of monarchs on the masses.

\footnotetext{
${ }^{57}$ Huangong (?-643 BC.), named Xiaobai 小白, as the King of State Qi, was one of the "Five Hegemons" in the Spring and Autumn Period.

${ }^{58}$ Chinese original: 蜜戚飯牛於車下, 望桓公而悲, 擊牛角, 疾商歌. 桓公聞之, 扶其僕之 手曰: “異哉！此歌者非常人也.”命後車載之. 桓公反至, 從者以請. 桓公曰: “賜之衣冠, 將見之.” 蜜戚見, 說桓公以合境內. 明日復見, 說桓公以為天下. 桓公大說, 將任之. (新序・ 雜事五).

${ }^{59}$ Shang (approximately 1060-1046 BC.) is the second Dynasty in archaic Chinese History.
} 
Folio 3, line 4-5:

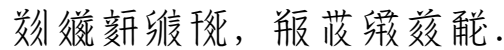

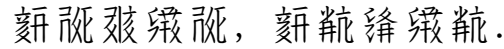

[Monarchs are like containers, masses are like water.

If the container is round, water will be round; if the container is quadrate, water will be quadrate.]

Chinese tentative reconstruction:

君者器也, 民者水也.

器圓則水圓, 器方則水方.

Here the word "container" is used as a general term for both plate and pot. This maxim first appears in the chapter 12 of Xunzi, reading: "Monarchs are like plates, if the plate is round, water will be round; Monarchs are like pots, if the pot is quadrate, water will be quadrate. ${ }^{, 60}$ By contrast, a quotation in volume 73 of the Yiwen Leiju is much closer to that in BCT, which reads: "Monarchs are like plates, masses are like water. If the plate is round, water will be round; if the plate is quadrate, water will be quadrate." ${ }^{\prime 1}$

The aim of the next couplet is to specify the above metaphor, in which the two figures concerned are Huangong 桓公 (xwã kow 刓谣併) and Zoujun 鄒君 (tshew njij 卯席) $)^{62}$ respectively.

\section{Folio 3, line 5-7:}

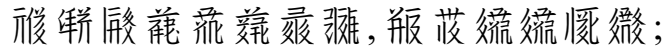

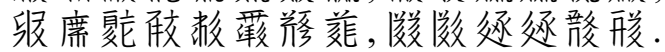

[Huangong was fond of wearing purple clothes, therefore all the masses wore so.

Zoujun was fond of wearing feather hat ${ }^{63}$, therefore all the officials wore so.]

Chinese tentative reconstruction:

桓公好服紫而民庶人人盡服, 鄒君好冠縜而臣宰所在皆冠.

\footnotetext{
${ }^{60}$ Chinese original: 君者, 盤也, 盤圓而水圓; 君者, 孟也, 孟方而水方. (荺子・君道).

${ }^{61}$ Chinese original: 䓪卿子曰: 君者盤也, 民者水也, 盤圓則水圓, 盤方則水方. (藝文類 聚, 卷七十三).

${ }^{62}$ There might be a slight error of Tangut transcription, for the Chinese zou 鄒 should be pronounced tśew, not tshew in Tangut.

${ }^{63}$ Tangut 夏㢈交 (feather) is a misunderstanding of Chinese ying 縜 (hatband).
} 
Both stories come from chapter 32 of Hanfeizi: ${ }^{64}$

King Qi Huangong was fond of wearing purple clothes, therefore people of the whole state were in purple. At that time, five plain color clothes were not equal to one purple in price. Huangong worried about that and said to Guan Zhong ${ }^{65}$ : "That I am fond of wearing purple makes purple extremely expensive and the people of the whole state are fond of purple endlessly. How can I face stop this?" Guan Zhong said: "If intending to stop this, why does not Your Majesty try to give up wearing purple? Telling servants around: I dislike the smell of purple. ${ }^{66}$ Just when people around coming in purple, you have to say: Draw back a little, for I dislike the smell of purple." Huangong said: "Well." In one day there were not any officials wearing purple, in the next day nobody wore purple in the capital, after three days nobody wore purple within the borders.

That Monarch Zoujun ${ }^{67}$ was fond of long hatband and all people around wore it and it made a long hatband very expensive. Zoujun worried about that and asked people around. People around said: "The reason of expensiveness is that Your Majesty is fond of wearing it, so the masses wear it as well." After that, Zoujun shortened his hatband and went out, thus nobody wore long hatbands within the state.

The following two lines on folio 3 are beyond my ability to decipher word by word. What follows in folio 4 (Fig. 4), not in connection in context with the previous folio, is a folk maxim without rhythm, telling not to be hypercritical too much.

\footnotetext{
${ }^{64}$ Chinese original: 齊桓公好服紫,一國盡服紫. 當是時也, 五素不得一紫. 桓公患之, 謂 管仲曰: “寡人好服紫, 紫貴甚, 一國百姓好服紫不已, 寡人奈何?”管仲曰: “君欲止之, 何不 試勿衣紫也? 謂左右曰: 吾甚惡紫之臭. 於是, 左右適有衣紫而進者, 公必曰: 少卻, 吾惡紫 臭.”公曰: “諾.”於是日, 郎中莫衣紫; 其明日, 國中莫衣紫; 三日, 境內莫衣紫也.……鄒君 好服長縜, 左右皆服, 長縜甚貴. 鄒君患之, 問左右. 左右曰: “君好服, 百姓亦多服, 是以貴.” 君因先自斷其縜而出, 國中皆不服長縜. (韓非子・外儲說左上).

${ }^{65}$ Guan Zhong (approximately 723-645 BC.), named Yiwu 夷吾, as the Premier of State Qi, was the most outstanding politician in the Spring and Autumn Period. He assisted King Qi Huangong in reform to make his State rich and its military force efficient. Under his instruction, Qi became the most powerful State at that time.

${ }^{66}$ It is said that the purple dyestuff was extracted from the root of comfrey and there was a frowzy smell brought about in the process of extraction.

${ }^{67}$ State Zou is generally called Zhu 制, was a small dependent state to State $\mathrm{Lu}$ in the Spring and Autumn Period. The monarch of State Zou mentioned here remains unknown except his surname Cao 曹.
} 
Folio 4, line 1-2:

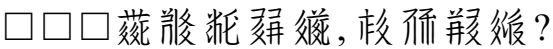

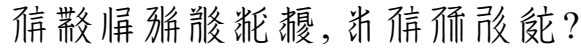

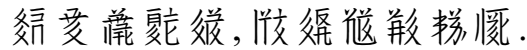

[A single tree dried up (in the forest), does it hurt the forest?

A single grass drifting in the sea, is it fault of the sea?

Just as a bristle on fur, one seeks a flaw by blowing the fur. ${ }^{68}$ ]

Chinese tentative reconstruction:

(叢林間) 枯一株樹, 而何害於林?

大海內漂一株草, 豈歸罪於海?

譬如皮生硬毛, 吹毛求疵一般。

In the following, the literary style returns to the antithetical couplet. First, the regularity of natural world is emphasized.

\section{Folio 4, line 2-3:}

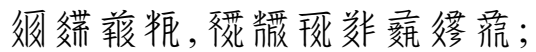

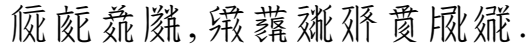

[Four seasons are changing, Spring and Autumn take the regularities of life; Five Elements ${ }^{69}$ are succeeding, water and fire manifest their gentle natures.]

Chinese tentative reconstruction:

四季更迭, 春秋有生滅之理; 五行相襲, 水火顯柔和之性.

According to natural regularities, monarchs should govern all things on earth by their virtue and morality.

\section{Folio 4, line 3-4:}

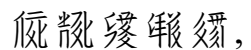

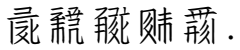

${ }^{68}$ It seems that this metaphor is derived from the Chinese idiom chui mao qiu ci 吹毛求疪 (seeks a flaw by blowing the fur), which means one constantly focused on the smallest defects of others.

69 "Five Elements" in traditional Chinese philosophy, including metal, wood, water, fire and earth, are said to be the basic factors to form all the matters in the universe. 
[It is a devotion to breed Five Cereals, ${ }^{70}$

It is a merit to manage all things.]

Chinese tentative reconstruction:

飬五穀為信,

治萬物成功.

Folio 4, line 4-5:

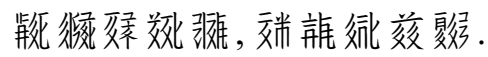

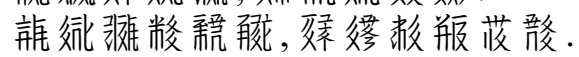

[Wind and rain depend on benevolence, yin and yang ${ }^{71}$ accord with virtue. Governing affairs depends on yin and yang, enlightening multitude relies on benevolence.]

Chinese tentative reconstruction:

風雨依乎仁, 陰陽合於德.

依陰陽治諸事, 以仁義化庶民.

The following topic turns back to telling historical stories, emphasizing the importance of governing the country by law at first. The figures mentioned are

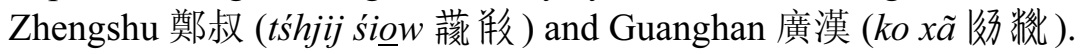

\section{Folio 4, line 5-7:}

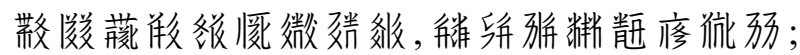

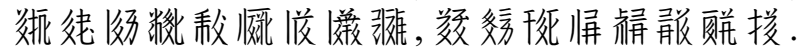

[Because Minister Zhengshu made the laws lenient, many bandits gathered in bush;

For Eastern ${ }^{72}$ Guanghan had a severe majesty, all bullies within Jingzhao City $^{73}$ were wiped out.]

70 "Five Cereals" is a Chinese joint name for grain crops, including rice, millet, barley, wheat and bean.

${ }^{71}$ Yin and yang, as the fundamental of ancient Chinese philosophy, indicate the negative and positive which constitute the universe and determine the cosmic order by their combination.

${ }^{72}$ Tangut word njij dzji 抳律 (east-cover) is inscrutable to decipher. Here I tentatively translated it as "eastern" by considering that Guanghan was a native of Zhuo Prefecture 派郡 (now in Hebei Province) which located to the east of the Capital Jingzhao.

73 “Jingzhao", now Xi'an City, was written mistakenly as tśhjiw kjij 数数 (Chin. zhaojing 兆京) by a careless Tangut transcriber. 
Chinese tentative reconstruction:

大臣鄭叔律令寬鬆,而草䒭之中盜者多集;

東方廣漢威儀剛猛, 故京兆城內豪強盡絕.

Zhengshu, also called Taishu, a minister of State Zheng, was the son of Zichan. Zichan, named Gongsun Qiao 公孫僑, as Prime Minister of State Zheng, was one of the most outstanding politicians in the Spring and Autumn Period. The story about his son comes from chapter The $20^{\text {th }}$ year of Zhaogong in Zuozhuan: ${ }^{74}$

Zichan of State Zheng was ill, he told his son Taishu: "After I die, you for sure will administrate the politics. Only a virtuous leader can govern the masses by lenience, and do not exceed severity. Fire is severe; the masses look out and fear it, so few of them die there. Water is weak, the masses go close and disregard it, so lots of them die there. For this reason, lenience is more difficult." After several months Zichan died of illness. When Taishu became the administrator, he did not care severity, but took lenience, then bandits increased in State Zheng.

Guanghan, having his surname Zhao 趙, lived in the first century BC., was the governor of the capital and one of the most famous upright officials in Western Han Dynasty. The relevant story comes from his biography in volume 76 of Hanshu: ${ }^{75}$

Guanghan was a man of force, being proficient in official affairs. In meeting officials or masses, sometimes he did not sleep until daybreak ... As the governor of Jingzhao Prefecture, he ruled clever and honestly, severely restraining bullies and giving official position to ordinary people. The masses have thought back of him and have praised him so far.

A folk maxim about not taking ill-gotten gains is inserted between the contexts.

\section{Folio 4, line 7:}

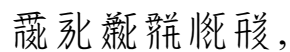

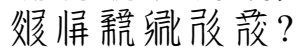

[It is not obtaining to get a sword on the roadside, Is it stashing to hide properties into the tomb?]

\footnotetext{
${ }^{74}$ Chinese original: 鄭子產有疾, 謂子太叔曰: “我死, 子必為政. 唯有德者能以寬服民, 其次莫如猛. 夫火烈, 民望而畏之, 故鮮死焉. 水懦弱, 民狎而習之, 則多死焉, 故寬難.” 疾數月而卒. 太叔為政, 不忍猛而寬, 鄭國多盜. (左傳・昭公二十年).

75 廣漢為人強力, 天性精於吏職. 見吏民, 或夜不寝至旦 ... 為京兆尹廉明, 威制豪強, 小民得職. 百姓追思, 歌之至今. (漢書・趙廣漢傳).
} 
Chinese tentative reconstruction:

道旁得劍不為取,

墓裏有財豈為藏?

The following couplet emphasizes that extravagance will definitely lead the country to decline and fall, in which the two figures mentioned are $\mathrm{Lu}$ Zhuanggong 魯莊公 (lu tśiow kow 弹邪件并) and Xia Kangdi 夏康帝 (xia

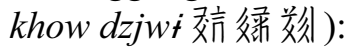

Folio 4, line 8 - Folio 5, line 1:

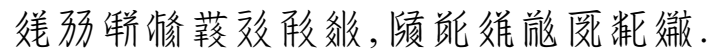

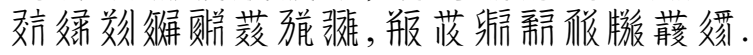

[It is because Lu Zhuanggong's palace was gorgeous that the state became weak and disordered at last.

Emperor Xiakang's palace was beautiful that the masses became indigent and perished.]

Chinese tentative reconstruction:

魯莊公殿堂華美, 故國家衰弱至於亂;

夏康帝宮室莊嚴, 故民庶貴乏致滅亡。

Lu Zhuanggong (706-662 BC.), named Ji Tong 姬同, was the 16th monarch of State Lu in the Spring and Autumn Period. The Tangut word pju rjir 落漖 (palace) seems to originate from Chinese tai 臺 (tower, high platform), see chapter The $32^{\text {nd }}$ year of Zhuanggong in Zuozhuan: ${ }^{76}$

King Zhuanggong built a tower close to the Zhangs, ${ }^{77}$ where he saw Mengren ${ }^{78}$ and intended to fornicate with her but was refused. Then he got her promise to be his concubine and took an oath by cutting arms.

According to Zuozhuan, the later political turmoil in State Lu was caused by the feuding among Zhuanggong's three younger brothers, which was irrelevant to building the gorgeous palace.

Xiakang, generally called Taikang 太康, was the second emperor of Xia Dynasty in legend. It was said in Lisao 離騷 by Qu Yuan that he lost the country for his indulgent amusement: Xiakang yu yi zizong 夏康娛以自縱 (Xiakang amused himself with indulgence).

\footnotetext{
${ }^{76}$ Chinese original: 公築臺臨黨氏, 見孟任, 從之閟. 而以夫人言, 許之, 割臂盟. (左傳・ 莊公三十二年).

77 "Zhangs" here indicate the family of minister surnamed Zhang.

${ }^{78}$ Mengren was the firstborn daughter of minister Zhang.
} 


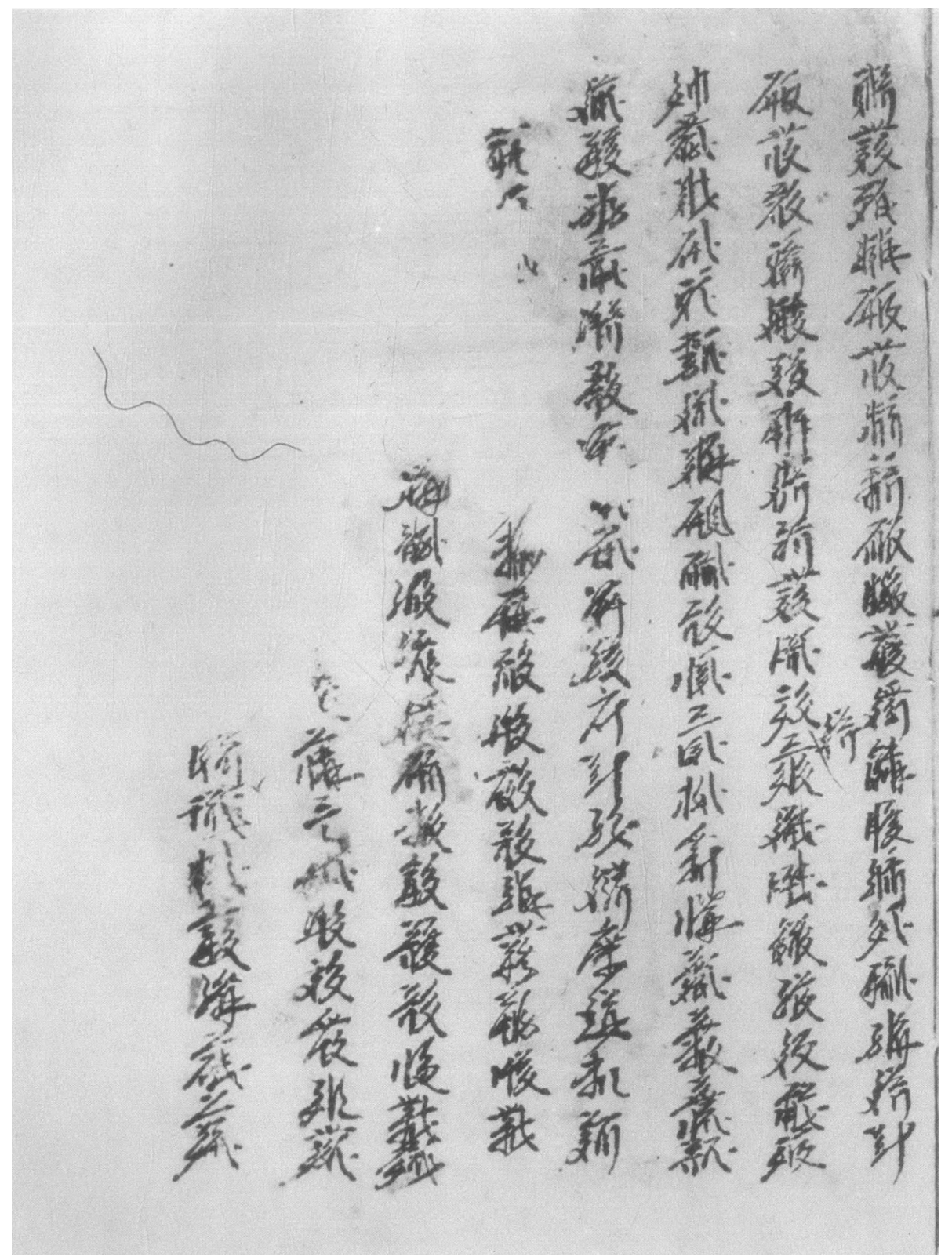

Fig. 5

The fifth folio of Brief Collection by Taizong 


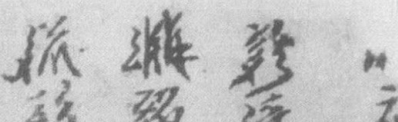

统教涪神

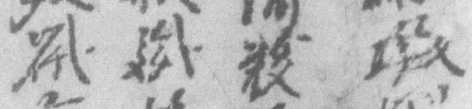

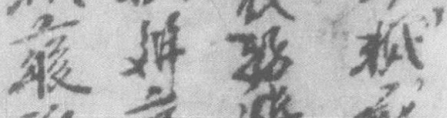

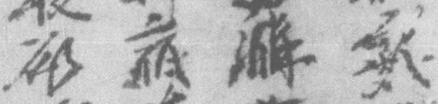

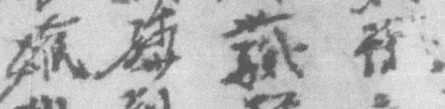

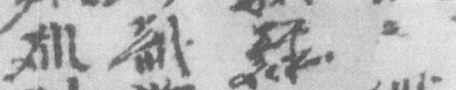

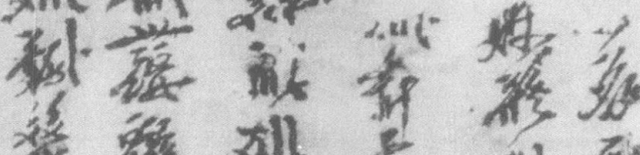

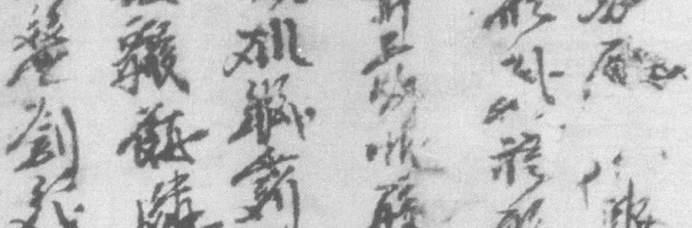

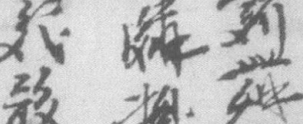

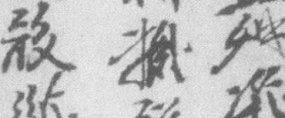

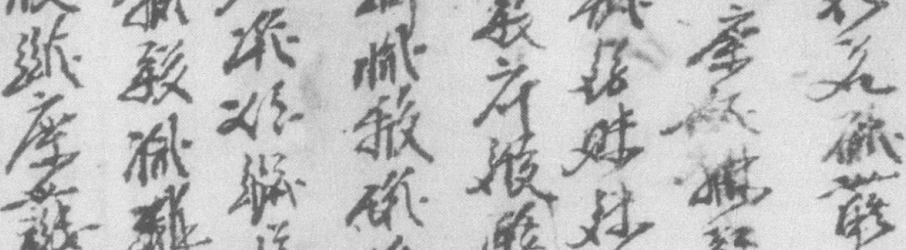

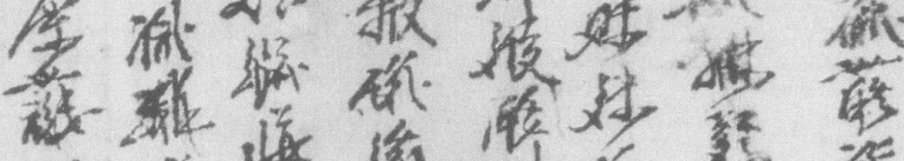

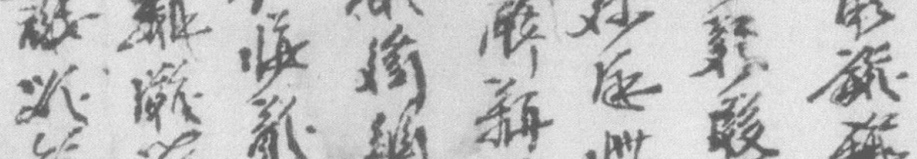

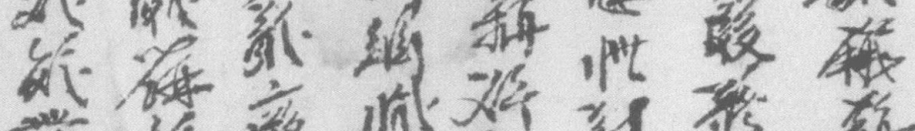

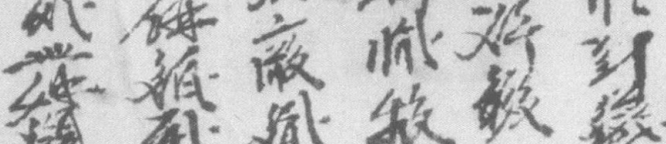

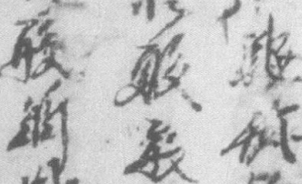

能

$x^{5}$

/

. 
The next couplet follows the former subject of advocating a simple life and objecting to luxury, in which the first figure mentioned is Yao 堯 (jiw 废畨) but the second one, tsow we tśhjow 牶䵊祈, is quite incomprehensible. Here, I believe that the second character of the name is a mistake caused by the similarity of two Chinese characters. Considering the Tangut $w e \tilde{e}$ 傕 is always used to transcribe Chinese wen 文 which is similar to tai 太 in appearance, especially shown in cursive handwriting, we may decide that the original must have been Zuo Taichong 左太沖 under the help of Chinese classics.

\section{Folio 5, line 1-2:}

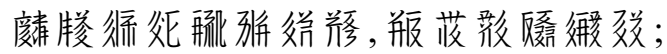

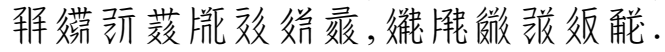

[The masses heaped praise on Emperor Yao for he made soil steps and thatched huts.

Family members heaped irony to Zuo Taichong for he complimented luxury buildings.]

Chinese tentative reconstruction:

堯天子造土階茅茨, 民庶齊聲讚歎;

左太沖愛屋舍莊嚴, 鄉人交口譏些.

The legend about Yao making soil steps and thatched huts for himself to live in can be found in volume 74 of Jiutangshu: ${ }^{79}$

In the past Tang Yao lived in a thatched hut with soil steps, Xia Yu wore poor clothes and ate simple food. I know that things like these cannot reappear nowadays.

Zuo Taichong, i.e., Zuo Si 左思 (approximately 250-305), was one of the most famous writers in Western Jin period. His literary work Sandu Fu 三都 賦 ${ }^{80}$ was spread widely at that time, but it seems that there were people who sneered at him, as recorded in the second volume of Shishuo Xinyu: ${ }^{81}$

When Zuo Taichong just finished his work Sandu Fu, somebody at that time heaped irony to him.

\footnotetext{
${ }^{79}$ Chinese original: 昔唐堯茅茨土階, 夏禹惡衣菲食. 如此之事, 臣知不可復行於今. (舊唐書・馬周傳).

${ }^{80}$ Sandu Fu 三都賦 is a joint title of his antithetical prose for the capitals of Wei, Shu, Wu in the Three Kingdoms Period. In these works the prosperity of the cities are excessively complimented by flowery rhetoric.

${ }^{81}$ Chinese original: 左太沖作三都賦初成, 時人互有譏些. (世說新語・文學四).
} 
The next two sentences, not in antithetic genre, are metaphors comparing to the advice that it should not treat noblemen as common people.

\section{Folio 5, line 2-4:}

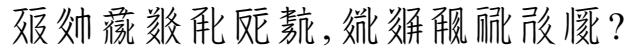

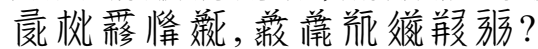

[To feed a swift horse as precious jade, is it the way to go together with the horses before or after it?

To treat a sword equal to gold of ten thousand liang $^{82}$ in price, is it used as a tailor's needle?]

Chinese tentative reconstruction:

餵養千里寶玉馬, 豈與首尾之馬並馳?

萬兩金價劍, 豈同裁縫之針?

In the following there come two famous stories of Emperor finding sages at unobserved places, but some characters on the original are lost:

\section{Folio 5, line 4-6:}

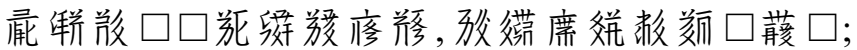

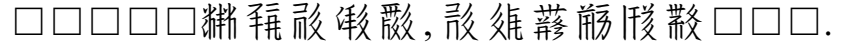

[Taigong, as a fisher beside the (Weishui) River, was invited to be Prime Minister by Zhou Wenwang;

(Fu Yue), as a walling worker in..., was promoted directly to be a minister by Yin Gaozong.]

Chinese tentative reconstruction:

太公, 渭水河濱捕魚者也, 周文王請而為丞相;

傅說， $\square \square \square$ 中版築之人，殷高宗逕擢為大夫。

The legend of Jiang Taigong Lü Shang's fishing recorded in volume 32 of Shiji: $:^{83}$

${ }^{82}$ Liang 兩 is a Chinese unit of measure $(\approx 14$ grams at that time $)$.

${ }^{83}$ Chinese original: 呂尚盖嘗窮困, 年老矣, 以魚釣奸周西伯. 西伯將出獵, 卜之, 曰: “所 獲非龍非麗, 非虎非罢, 所獲霸王之輔.”於是周西伯獵, 果遇太公於渭之陽. 與語, 大説, 曰: “自吾先君太公曰: 當有聖人適周, 周以興. 子真是邪? 吾太公望子久矣.”故號之曰太公望, 載與俱歸, 立為師. (史記・齊太公世家). 
Lü Shang, being destitute in his early age, came into contact with Zhou Xibo ${ }^{84}$ by fishing when he was old. Xibo would go hunting and divined for it, the answer was: "The proceeds will be neither dragons, nor a tiger, nor a bear, but an assistant for ruling the state." Then Zhou Xibo went hunting and really met Taigong on the north bank of the Weishui River, ${ }^{85}$ talking with him and being greatly delight, he said: "My ancestor monarch Taigong ${ }^{86}$ said that there should be a sage coming to Zhou and Zhou Dynasty would be prosperous with him. It is really you? My Taigong has expected you for a long time." For that, Xibo named him Taigong Wang, went back with him in a cart and appointed him as preceptor.

The legend of Fu Yue's walling recorded in volume 3 of Shiji: ${ }^{87}$

Emperor Wuding ${ }^{88}$ saw a dream with a sage named Yue. He looked at all the ministers and officials for a person he saw in the dream, but all of them were not him. Thus he ordered officials to search for the sage among the civilians and then found Yue in Fuyan ${ }^{89}$ when Yue was serving sentences as a walling worker there. Wuding interviewed him and said: "It is just him." By receiving and talking with him, Wuding found that he was really a sage, and then appointed him to be Prime Minister, bringing a great order throughout the state. Thus Wuding gave him a surname according to Fuyan and named him Fu Yue.

The upper left part on folio 5 and the upper right part of folio 6 (Fig. 6) are fragmentary, and I am not able to decipher the relevant lines word by word. What we can see with certainty is there mentioned a story of Emperor Shun and a short phrase “fearing the four knowings" (Tang. ljir nwa kja 眛版跤, Chin. wei sizhi 畏四知), the latter evidently comes from the story of Yang Zhen 楊震 $(?-124)$ in volume 84 of Houhanshu: ${ }^{90}$

${ }^{84}$ Zhou Xibo is the title of Ji Chang 姬昌 before he overthrew Yin Dynasty and became King Zhou Wenwang. "Xibo" means "Earl in the West".

${ }^{85}$ Weishui 渭水 is a river near Chang' an (now Xi'an City).

${ }^{86}$ Here the word "Taigong", including the next one, does not indicate Lü Shang, but a certain ancestor of Xibo. "Taigong" means "grandfather".

${ }^{87}$ Chinese original: 武丁夜夢得聖人, 名曰說. 以夢所見視最臣百吏, 皆非也. 於是廼使 百工營求之野, 得說於傅巌中. 是時說為胥靡, 築於傅巖, 見於武丁. 武丁曰: “是也.”得而 與之語, 果聖人. 舉以為相, 殷國大治. 故遂以傅䉷姓之, 號曰傅說. (史記・殷本紀).

${ }^{88}$ Wuding, the $23^{\text {rd }}$ Emperor of Yin (Shang) Dynasty in legend, is priced to be the Lord of Resurgence at that time.

${ }^{89}$ Fuyan is an ancient name of place to the east of Pinglu County, Shanxi Province.

${ }^{90}$ Chinese original: 楊震 .... 當之郡, 道經昌邑, 故所舉荆州茂才王密為昌邑令, 謁見. 至夜, 懷金十斤以遺震. 震曰: “故人知君, 君不知故人, 何也?”密曰: “暮夜無知者.”震曰: “天知, 神知, 我知, 子知. 何謂無知?”密愧而出. (後漢書・楊震傳). 
When Yang Zhen went to the Prefecture via Changyi County, County magistrate Wang Mi asked for an interview for Zhen recommended him from a scholar in Jingzhou Prefecture. At night he went with ten $\mathrm{jin}^{91}$ of gold to present Zhen. Zhen said: "Why the old friend knows you but you do not know the old friend?" Mi said: "Nobody knows at night." Zhen said: "The Heaven knows, the deity knows, I know and you know. What do you mean by nobody knows?" Mi was ashamed and got out.

The story of Yang Zhen's "fearing the four knowings" must be one of the widely spread literary allusions at that time in the Silk Road, for we see it was mentioned in both Tangut versions of Forrest of Categories (SHI et al. 1993) and Collection of Upright Behaviors (SUN 2011). Besides, it is also mentioned in the Tibetan version of an untitled Confucian Maxims from Dunhuang (STEIN 1992).

The sixth folio (Fig. 6) is severely damaged, in which the only complete couplet can be read over is telling how to be a wise and hard-working administrator. The two figures mentioned are Zhao Guanghan 趙廣漢 (tśhjiw

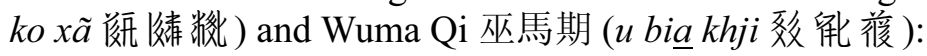

Folio 6, line 7-8:

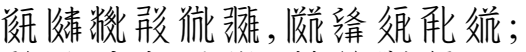

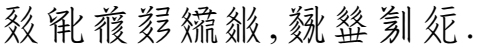

[Zhao Guanghan possesses wisdom, knowing the price of horse by asking about goat;

Wuma Qi possesses discourse, sitting in the government hall at dawn and leaving at night. ${ }^{92}$ ]

Chinese tentative reconstruction:

趙廣漢有智，故問羊知馬;

巫馬期有語, 故星入星出.

Zhao Guanghan already appeared in previous text, but here the Chinese character guang 廣 is transcribed by a homophone ko 畨 than $k o$ 绛. There is a story of his finding reality in a roundabout way in volume 76 of Hanshu: ${ }^{93}$

${ }^{91}$ Jin $斤$ is a Chinese unit of measure $(\approx 220$ grams in Han Dynasty).

${ }^{92}$ Here is misunderstanding of the Chinese phrase xing ru xing chu 星入星出 (to be back home with stars and go out with stars), i.e., he is so busy that he goes out for official affairs from early-morning to late-night without leisure.

${ }^{93}$ Chinese original: 廣漢 ... 尤善為鉤距, 以得事情. 鉤距者, 設欲知馬賈, 則先問狗, 已 問羊, 又問牛, 然後及馬, 參伍其賈, 以類相准, 則知馬之貴賤不失實矣. (漢書・趙廣漢傳). 
Guanghan was especially good at getting realities by gouju. ${ }^{94}$ Gouju means that if anyone want to know the price of a horse, he should ask about that of a dog first, then that of a goat, then that of an ox, then that of a horse at last, weighing their prices analogically, thus he knows a real price of a horse.

Wuma Qi (521-? BC.), named Shi 施 with a given name Ziqi 子期, was one of the disciples of Confucius and famous for his diligence. His story can be found in the second volume of Hanshi Waizhuan: ${ }^{95}$

In administrating Shanfu County ${ }^{96}$ that Zijian ${ }^{97}$ played zither without leaving the hall brought Shanfu in order. That Wuma Qi went out and back accompanied by stars, doing everything personally without staying also brought Shanfu in order.

The last four folia of BCT are too fragmentary in illegible cursive handwriting to be recognized, in which I can only read out a character dźjwa 瓶 (finish) indicating the end of the text. After that there is a fragmentary prose which might be estimated as a postscript of the booklet, but its content remains unknown to us.

\section{Nature of the manuscript}

Although a complete satisfying translation is not given in the present paper, the above narrations and translations do not show any relations between BCT and Emperor Tang Taizong. The parallel facts may be found in folk literature of Northwestern China at that time, since we see that in materials excavated from Dunhuang there are manuscripts entitled Taigong Jiajiao 太公家教 (Family instructions by Taigong) and Wuwang Jiajiao 武王家教 (Family instructions by Emperor Wuwang) which both have nothing to do with Jiang Taigong and Wuwang in early Zhou Dynasty. Actually we all know it is a tradition in ancient China that folk authors used to insert the names of famous historical figures in the title of their own productions.

There are various primary readers excavated from the Mogao Grottoes of Dunhuang, ${ }^{98}$ in which we cannot find a creation in the same literary style

\footnotetext{
${ }^{94}$ Gouju 鉤距 is a sort of ancient weapon with a hook at the top of a long pole. Here it was used as a metaphor for saying something in a roundabout way.

${ }^{95}$ Chinese original: 子賤治單父, 彈鳴琴, 身不下堂, 而單父治. 巫馬期以星出, 以星入, 日夜不處, 以身親之, 而單父亦治. (韓詩外傳卷二).

${ }^{96}$ Ancient Shanfu County locates in today's Heze City of Shandong Province.

${ }^{97} \mathrm{Fu}$ Zijian 宓子賤 (?-445 BC.) was another disciple of Confucius.

${ }^{98}$ Some of the works were selected and studied by Zheng and Zhu (2002). According their classification, perhaps our BCT might be put into the "Primary readers of the morality".
} 
of BCT, i.e., there are not any works compiled by the style of mixinf ancient allusions and current maxims. What is more, although there are not any consistent subjects throughout the text, BCT shows a distinctive feature from others else in Dunhuang that it might have been made more specifically for noble children, not common people, with the purpose of expecting them to increase their historical knowledge and understand some principles in the meantime for assisting monarchs in future. This explains the fact that in BCT there mentions lots of monarchs, administrators and other outstanding persons but no moral preaches given by a senior to juniors as those in Taigong Jiajiao and Wuwang Jiajiao.

In the Institute of Oriental Manuscripts, Russian Academy of Sciences, RAS, there is a plentiful collection of original Tangut maxims compiled by a Xixia official scholar (Kychanov 1974), in which we cannot find any couplets identical with those collected in BCT. If we believe that almost all of the folk maxims spread in Xixia are included there, we may estimate with some certainty that those in BCT are intrinsic in its Chinese original, but I have no idea how to explain why the folk maxims were inserted into ancient literary allusions to form a book discordant in literary style. Maybe the Chinese original was finished by two persons, the first one was the start-up author and the second one was a careless transcriber who mixed two different manuscripts together to form a miscellaneous basis for the Tangut translator to rely on.

Comparing with most authors of the primary readings in Dunhuang, the educational level of the BCT author is evidently high er. Even we may estimate him as a learned official in government of Tang or Song Dynasty than a private teacher in backcountry, whose social role determined his vision limited within elites than ordinary masses. Accordingly, the readers presupposed by the author in his compilation might have been descendants of noble families, not of common villagers, because what the latter need most is to cultivate the awareness of respecting the old and having the ability of running the household industriously and frugally, while a high post with matched salary is an elusive dream for most of the common people in their whole life. So far it has been not difficult to understand that the narrow readers of BCT determined it being given cold shoulder by civilians, and it is just this imperfection made it being not preserved until nowadays as the numerous manuscripts of primary readers in Dunhuang. 


\section{References}

GorbaCHEVA Z.I. and KychanOv E.I. 1963: Tangutskie rukopisi i ksilografy [Tangut manuscripts and xylographs], Moscow: Izdatel'stvo vostochnoj literatury.

KyCHANOV, E.I. 1974: Vnov'sobrannye dragotsennye parnye izrechenija [Newly collected precious paired sayings], Moscow: Nauka.

Li Fanwen 李範文 1997: Xiahan Zidian 夏漢字典 [A Tangut-Chinese Dictionary], Beijing: China Social Sciences Press.

NIE Hongyin 聶鴻音 2012: Xixiaben Taizong Zeyao chutan 西夏本《太宗擇要》初探 [A preliminary research on the Tangut version Brief Collection by Taizong], Ningxia Shifan Xueyuan Xuebao, 2012(2), 55-59.

NisHIDA Tatsuo 西田龍雄 1999: Seikago butten mokuroku hensan jō no sho mondai 西夏語仏 典目錄編纂上の諸問題 [Various problems on cataloguing Tangut Buddhist canons], in E.I. Kychanov, Katalog tangutskikh buddijskikh pamyatnikov [Catalogue of Tangut Buddhist Monuments], Kyōto: Kyōto University.

SHI Jinbo 史金波, Huang Zhenhua 黃振華, Nie Hongyin 聶鴻音 1993: Leilin Yanjiu 類林研究 [Studies on the Forrest of Categories], Yinchuan: Ningxia People's Publishing House.

SteIN, R.A. 1992: Tibetica Antiqua VI, Maximes confucianistes dans deux manuscripts de Touen-houang, Bulletin de l'Ecole française d'Extrême-Orient 79, 1, 9-17.

SuN Bojun 孫伯君 2011: Xixiawen Zhengxing $J i$ Kaoshi 西夏文《正行集》考釋 [A textual research of Tangut version Collection of Upright Behaviors], Ningxia Shehui Kexue 2011(1), 87-94.

ZHENG Acai 鄭阿財 \& Zhu Fengyu 朱鳳玉 2002: Dunhuang Mengshu Yanjiu 敦煌蒙書研究 [Studies on primary readers of Dunhuang], Lanzhou: Gansu Education Publishing House. 